Chapter 4

\title{
Nutrients and Organic Matter Removal in a Vertical-Flow Constructed Wetland
}

\author{
Silviya Lavrova and Bogdana Koumanova \\ Additional information is available at the end of the chapter \\ http://dx.doi.org/10.5772/56245
}

\section{Introduction}

Constructed wetlands are promising engineering technique that reproduce the conditions of the natural wetlands [1]. They have high water treatment capacity because of the intensive "work" of the plants and the microorganisms. Depending on the conditions various types of plants are growing: common reed (Phragmites australis), rush (Typha latifolia), iris, etc. (Fig. 1). These plants are stable toward the climatic changes and the quality parameters of the medium in which they are growing. The metabolism of the microorganisms plays an important role in the pollutants removal from wastewaters. The main chemical and physical processes are sedimentation, sorption, chemical oxidation, photo degradation, evaporation [2] as well as biotic processes such as aerobic/anaerobic degradation, plants accumulation, phytodegradation, phytoevaporation. Many publications demonstrate the removal of suspended solids, organic matter, nutrients and bacteria from wastewater in constructed wetlands. There are two types of constructed wetlands: surface flow wetlands systems and subsurface flow wetland systems. The latter are subsurface horizontal flow wetlands systems (Fig. 2) and subsurface vertical flow wetland systems (Fig. 3), [3-6]. They are characterized with the different extent of nutrients removal [7-10].

In the subsurface vertical-flow constructed wetlands (SSVFCW) the wastewater enters through the surface and flows in vertical direction slowly through the supporting material and the plant roots until reaching the bottom outlet zone. These systems are built with porous materials such as sand and gravel, that restrict the clogging. The package clogging was observed at high organic load of the system [11]. The recirculation of the wastewater is helpful to overcome this limitation. 


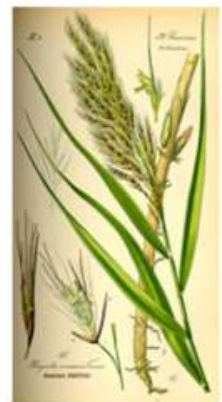

Phragmites australis

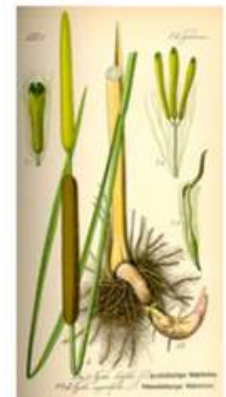

Typha latifolia

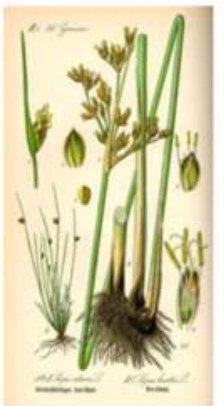

Scirpus lacustris

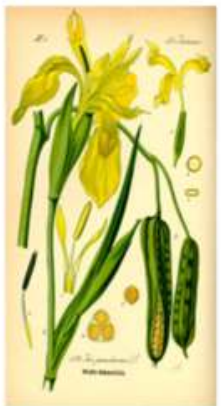

Iris pseudacorus

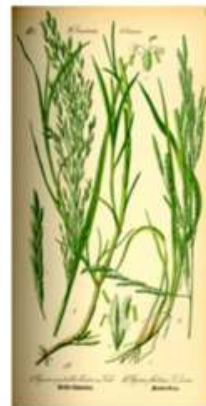

Glyceria maxima

Figure 1. Different types of plants growing in the wetland systems

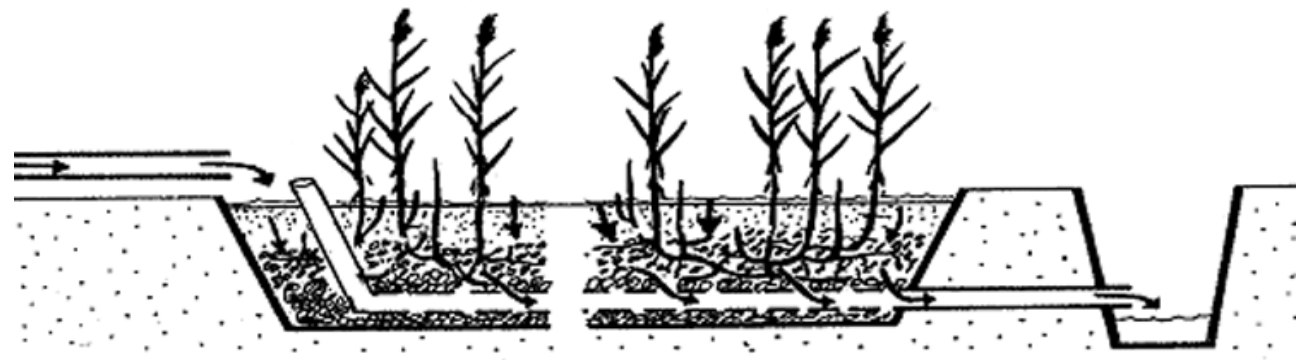

Figure 2. Subsurface horizontal-flow wetlands system 

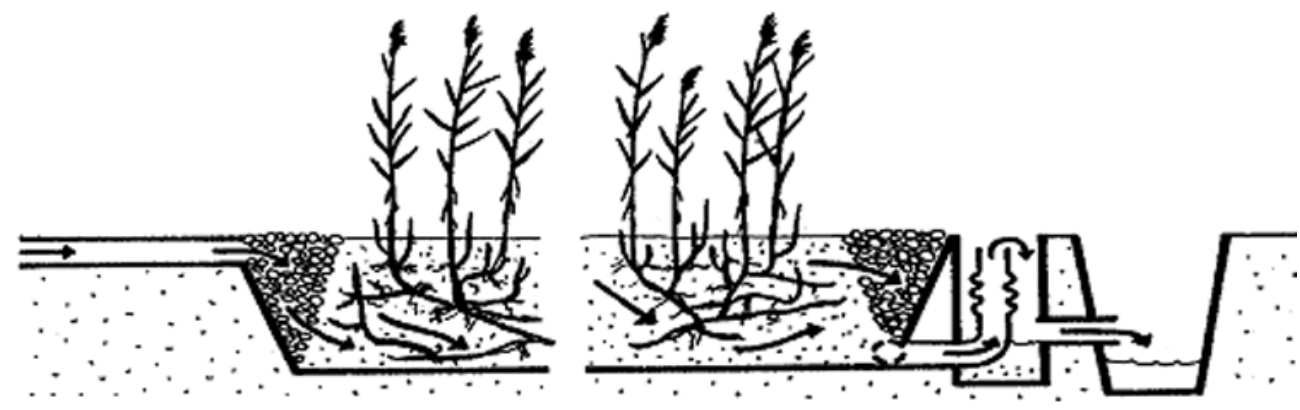

Figure 3. Subsurface vertical-flow wetlands system

Scholz and $\mathrm{Hu}$ [12] investigated various filter materials and macrophytes for the removal of lead and copper from wastewaters. They demonstrated the possibility to replace the expensive activated carbon and charcoal with the cheaper sand and gravel. Korkusuz [13] reports for the treatment of domestic wastewater in subsurface flow wetland with wasted granular slag and gravel. He obtained for both materials the removal of suspended solids (SS) $64 \%$ and $62 \%$, COD $-49 \%$ and $40 \%, \mathrm{NH}_{4}{ }^{+} \mathrm{N}-88 \%$ and $58 \%$, total nitrogen (TN) $-41 \%$ and $44 \%$, total phosphorus (TP) $-63 \%$ and $9 \%, \mathrm{PO}_{4}^{3-}-\mathrm{P}-60 \%$ and $4 \%$.

SSVFCW are used for treatment of industrial wastewaters from different sources: dyecontaining waters [14,15], pharmaceutically polluted waters [16], wastewaters from food industry [17], olive mill wastewaters [18], liquid waste activated sludge from a soft drink factory [19]. Gross et al. [20] reports for a novel method of recycling greywater for irrigation. The all SS and BOD were removed and about $80 \%$ of COD after $8 \mathrm{~h}$. A recirculating vertical flow constructed wetland was used also for treatment of domestic waters [21].

A combined subsurface vertical and horizontal flow constructed wetland system was designed for rular domestic wastewater treatment [22]. Several water quality parameters $\mathrm{pH}, \mathrm{BOD}$, COD, TSS, TKN, TP and faecal bacteria's number in both raw and treated wastewaters were monitored during a macrophytes life cycle. Seven mesocosm-scale constructed wetlands of different configurations were operated out-doors for 39 months to assess their ability to remove 
organic matter and nutrients from urban wastewaters [23]. F. Ye and Y. Li [24] have shown that nitrification/denitrification is the main mechanism for nitrogen removal from domestic wastewater in a novel constructed wetland configuration with three stages towery hybrid CW. Increased dissolved oxygen (DO) by passive aeration enhanced nitrification rates and additional organic matter supplied - for denitrification. In an installation, consisted of two settling tanks in series, a VFCW and a zeolite tank, Gicas and Tsihrintzis have studied household wastewater treatment [25]. The zeolite was found to offer additional removal of nitrogen, total phosphorus and organic matter. Significant reduction of total coliform and faecal coliform was achieved in a pilot scale VFCW in North Cairo planted with three kinds of plants [26]. The use of VFCW as a post treatment step will make possible the usage of the treated water for irrigation. The treatment effect of two pilot-scale VFCWs (one planted with Tipha latifolia and the second - with Phragmites australis) on municipal wastewaters and their suitability for irrigation reuse were studied in a 2-year experiment [27]. Zurita et al. [28] suggested that it is possible to produce commertial flowers in CW.

High rate nitrogen removal in a two-stage SSVFCW has been studied by Langergraben et al. [29]. The first stage used sand with a grain size of $2-3.2 \mathrm{~mm}$ and the second stage $-0.06-4 \mathrm{~mm}$. Better effluent quality as compared with to conventional single-stage VFCW was obtained. The Austrian effluent standards for organic matter and ammonium nitrogen were met and the average nitrogen removal efficiency was $53 \%$ without recirculation. A three-stage experimental CW system consisting of a vertical flow-gravel filtration bed without plants, a horizontal subsurface flow bed planted with Iris australis and a vertical subsurface flow bed planted with Phragmites australis in series were fed with primary treated domestic water [30]. The beds with plants produced effluents of better quality than that without plants. It was observed that the average removal efficiencies increased with the decrease of hydraulic loading rate. Panuvatvanich et al. studied the nitrification and denitrification potential of sand layer and the effect of percolate impounding regime on nitrogen transformation in four laboratory-scale units of vertical-flow CW fed once a week with faecal sludge [31]. Biabowiec et al. investigated the effects of reed and willow on bioremediation of landfill leachate in comparison with an unplanted control by measuring redox potential levels in the rhizosphere of microcosm systems in a greenhouse [32]. Molle et al. discussed the nitrogen removal in terms of the efficiency of the stages in a hybrid constructed wetlands plant designed for 100 person equivalent [33]. The first stage was composed of vertical filters, followed by a second stage of horizontal filters. Ouyang et al. [34] developed a model using the STELLA software for estimating nitrogen dynamics in a vertical-flow constructed wetland. It was established $18 \%$ of TN lost due to denitrification, $6 \%$ of TN was taken up by roots of a single plant and the rest of $22 \% \mathrm{TN}$ from the wastewater was removed from other mechanisms, such as volatilization, adsorption and deposition. Anaerobically pretreated domestic wastewater was treated in a hybrid CW with recirculation (first in horizontal-flow CW and then in vertical-flow CW). $98 \%$ total Kjeldahl nitrogen and $79 \%$ total nitrogen removal was obtained [35]. Li-Hua Cui et al. demonstrated the role of Cyperus alternifolius for the removal of total nitrogen in a VFCW [36]. Saeed and Sun [37] conducted comparative experiments in a lab-scale hybrid system with gravel, wood mulch and zeolite as medium. Average $\mathrm{NH}_{4}{ }^{+} \mathrm{N}, \mathrm{TN}$ and BOD removal percen- 
tages were over $99 \%, 72 \%$ and $97 \%$, respectively. The removal of Escherichia coli was 99,9\%. Nitrogen and phosphorus removal was studied also in [38-41].

Many investigations have been done of the influence of the operational parameters on the treatment efficiency of the constructed wetlands. Giraldi and Iannelli [42] used a capacitance probe to measure water content in a vertical flow CW pilot plant. They compared field measurements with data recorded in a laboratory apparatus. The effect of various design parameters has been studied by Stefanakis and Tsihrintzis [43]. Various porous media materials (carbonate material, material from river bed, zeolite and bauxite), two vegetation types (common reeds and cattails) and three total thicknesses of the porous media were used in 10 wetlands. Organic matter removal was good in all units, since it reached on the average $71,1 \%$ and $66,9 \%$ for BOD and COD, respectively. Nitrogen removal was $47,1 \%$ for TKN and $42,2 \%$ for $\mathrm{NH}_{4}{ }^{+}$-N. J.Ye et al. studied the vertical oxygen distribution in a VFCW treating domestic wastewater [44]. The main oxygen source was the atmospheric reoxygenation and approximately $50 \%$ of it was supplied to $0-10 \mathrm{~cm}$ below the water distribution system. Over $99,8 \%$ of the oxygen consumed was used for organic degradation and nitrification. The performance response of planted and unplanted wetlands to simulated wastewater with different ratios of carbon to nitrogen (2,5:1, 5:1 and 10:1) was studied during a 9-month period in greenhouse conditions by Zhao et al. [45]. At C/N ratio 5:1 was achieved a relatively high biological nitrogen removal efficiency and a low level of greenhouse gases flux [46]. Prochaska et al. studied the influence of the season, substrate, hydraulic load and frequency of application of simulated urban sewage on the performance of pilot-scale VFCW [47]. The ANOVA statistical model was applied to analyse the relationships between the main operational factors and the effluent $\mathrm{COD}, \mathrm{NO}_{2}^{-}-\mathrm{N}, \mathrm{NO}_{3}^{-}-\mathrm{N}, \mathrm{TN}$ and $\mathrm{PO}_{4}{ }^{3-}-\mathrm{P}$. The hydrodynamics of VFCW was tested with rhodamine WT and numerical modeling was used as written in [48]. The capacity of an on-site recirculating VFCW to withstand disturbances and highly variable influent quality was studied [49]. It was found that the general recovery is reached within $24 \mathrm{~h}$. Lihua Cui et al. treated domestic wastewater using three different slags, hydraulic loading rates, operational periods with and without plants for the removal of nitrogen and phosphorus [50]. Hybrid systems were compared at different $\mathrm{C} / \mathrm{N}$ ratios by Zhao et al. [51]. S. Prost-Boucle and $P$. Molle established the dependence of nitrification on the recirculation rate and seasons (temperature effect) [52]. Effect of loading, resting period, temperature, porous media, vegetation and aeration were studied by Stefanakis and Tsihrintzis [53]. In a review Saeed and Sun [54] discussed the dependence of nitrogen and organics removal on the environmental parameters, operating conditions and supporting media.

The role of the plants was studied toward the removal of nitrogen and phosphorus $[55,56]$. Iamchaturapatr et al. studied nutrient removal by 21 plants (18 emergent and 3floating plants) by area-based calculation and biomass-based calculations [57].

Bacterial carbon utilization in VFCW was studied by Tietz et al.[58]. A simple mass-balance approach was applied to explain the bacterially catalysed organic matter degradation. In another paper Tietz et al. [59] made a quantitative description of the microbial biocoenosis in subsurface VFCW fed with municipal wastewater. The microbial biomass was measured at 
different depths of planted and unplanted systems. Sleytr et al. demonstrated the influence of the plants on the rhizosphere community [60].

Based on Life Cycle Assessment (LCA) Fuchs et al. suggested that constructed wetlands have less environmental impact in terms of resource consumption and greenhouse gas emissions [61].

Different filter materials for phosphorus removal from wastewater in treatment wetlands have been studied [62, 63]. The potential of fragmented Moleanos limestone [64], wollastonite [65], crushed brick and palygorskite [66], a mixture of river sand and dolomite (10:1 w/w), [67] was investigated.

The landfill leachate is characterized with high nitrogeneous pollutants content. Investigations have been done on its purification in constructed wetlands. Four vertical-flow wetlands under predominately aerobic conditions were used for a mass-balance study in the transformation of nitrogeneous pollutants [68]. Landfill leachate was treated in a pilot-scale sub-surface CW planted with Cyperus haspan and three weeks retention time. Samples were tested for 13 parameters ( $\mathrm{pH}$, turbidity, color, TSS, COD, $\mathrm{BOD}_{5}, \mathrm{NH}_{4}{ }^{+}-\mathrm{N}, \mathrm{TP}, \mathrm{TN}, \mathrm{Fe}, \mathrm{Mg}, \mathrm{Mn}, \mathrm{Zn}$ ) and a high removal efficiency was obtained [69]. Justin et al. present a combination of landfill leachate pre-treatment in CW and subsequent reuse for the irrigation of grass and willows [70]. Six interconnected beds with horizontal and vertical subsurface water flow and planted with Phragmites australis were used. According to Bulk [71] CWs as a tertiary system or as an independent system could be a low-cost alternative for the treatment of leachate from old landfill sites. Leachate from a closed landfill was treated in an integral system consisted of extraction, aeration, settling, intermittent vertical sand filtration, a surface flow wetland with recycle and discharged in a river [72]. Experiments were conducted to treat a sanitary landfill leachate with high nitrogen and bacterial contents [73]. Mass balance analysis, based on total nitrogen contents of the plant biomass and dissolved oxygen and oxidation reduction potential values, suggested that $88 \%$ of the input total nitrogen were uptaken by the plant biomass. Lavrova and Koumanova studied the influence of recirculation in a lab-scale VFCW on the treatment efficiency of landfill leachate [74]. Comparison of horizontal and vertical CW systems for landfill leachate treatment with two types of material (gravel and zeolite) and planted with Typha latifolia was made by Yalcuk and Ugurlu [75]. Better $\mathrm{NH}_{4}{ }^{+}-\mathrm{N}$ removal performance was observed in the VF system with zeolite. Horizontal flow system was more effective in COD removal.

\section{Aim}

The aim of this study is to investigate treatment efficiency of the raw pig slurry and the landfill leachate in a lab-scale subsurface vertical-flow wetland (SSVFW) planted with Phragmites australis, in the lab-scale aerobic activated sludge bioreactor (ASR) and in an hybrid installation where the first stage includes an aerobic activated sludge bioreactor and the second stage - a subsurface vertical-flow wetland (ASR-SSVFW). 


\section{Material and methods}

Pig slurry was taken from a farm located in south-western part of Bulgaria and the landfill leachate was taken from a landfill situated in the north-western region in Bulgaria. After collection, the wastewater was allowed to settle overnight. After that the supernatant was treated. Table 1 summarizes the main characteristics of the influent wastewaters.

\begin{tabular}{|c|c|c|}
\hline \multirow[t]{2}{*}{ Parameter } & \multicolumn{2}{|c|}{ Influent } \\
\hline & Pig slurry & Landfill leachate \\
\hline $\mathrm{COD}, m g L^{-1}$ & $1535 \pm 502$ & $2940 \pm 140$ \\
\hline $\mathrm{BOD}, m g L^{-1}$ & $612 \pm 419$ & $230.5 \pm 26.5$ \\
\hline $\mathrm{NH}_{4}{ }^{+}-\mathrm{N}, m g L^{-1}$ & $322 \pm 87$ & $206.7 \pm 8.3$ \\
\hline $\mathrm{NO}_{3}{ }^{-}-\mathrm{N}, m g L^{-1}$ & 0 & $1.5 \pm 0.4$ \\
\hline $\mathrm{pH}$ & $7.2 \pm 1.1$ & $7.9 \pm 0.4$ \\
\hline
\end{tabular}

Table 1. Characteristics of the influent wastewater

The water samples were taken every day. The water samples have been examined for $\mathrm{pH}$, Chemical Oxygen Demand (COD), Biochemical Oxygen Demand (BOD), AmmoniumNitrogen $\left(\mathrm{NH}_{4}{ }^{+}-\mathrm{N}\right)$ and Nitrate-Nitrogen $\left(\mathrm{NO}_{3}{ }^{-}-\mathrm{N}\right)$ by standard methods [76].

\section{- Lab-scale subsurface vertical-flow wetland planted with Phragmites australis (SSVFW)}

The laboratory system consisted of sedimentation tank, subsurface vertical-flow wetland, peristaltic pump and storage tank of the treated water (Fig. 4). The SSVFW was made of Plexiglas with dimensions of $123 \mathrm{~mm}$ in diameter and $900 \mathrm{~mm}$ in height. The reactor was filled with $35 \div 55 \mathrm{~mm}$ round gravel with $300 \mathrm{~mm}$ height as bottom layer and top layer of $5 \div 25 \mathrm{~mm}$ gravel with a height of $500 \mathrm{~mm}$. Young Phragmites australis, obtained from comparatively clean area, was planted in the top layer of the SSVFW. After collection, the wastewater was allowed to settle overnight, the supernatant was diluted with tap water and then was treated. This was done to avoid possible damage of the plant because of the significant contamination of the raw pig slurry and landfill leachate. For increasing the purification capacity effluent recirculation was used [77-82]. The SSVFW was operated continuously in recirculation regime. The recirculation was employed at ratio of 1:1, giving SSVFW $1 \mathrm{~h}$ of wastewater-bed matrix contact and $1 \mathrm{~h}$ of effluent recirculation. The flow rate of the system was $80 \mathrm{ml} \mathrm{min}{ }^{-1}$ [80-82] and the hydraulic retention time was $0.9 \mathrm{~h}$. After filling the reactor with wastewater, the laboratory peristaltic pump was turned on and the water started to flow through the system for a period of one hour. After that, controlled by programmed electronic timer, connected with peristaltic pump, the water stopped moving and remained calm in the SSVFW for one hour. After one hour the peristaltic pump started again and the water began to flow again through the SSVFW. 


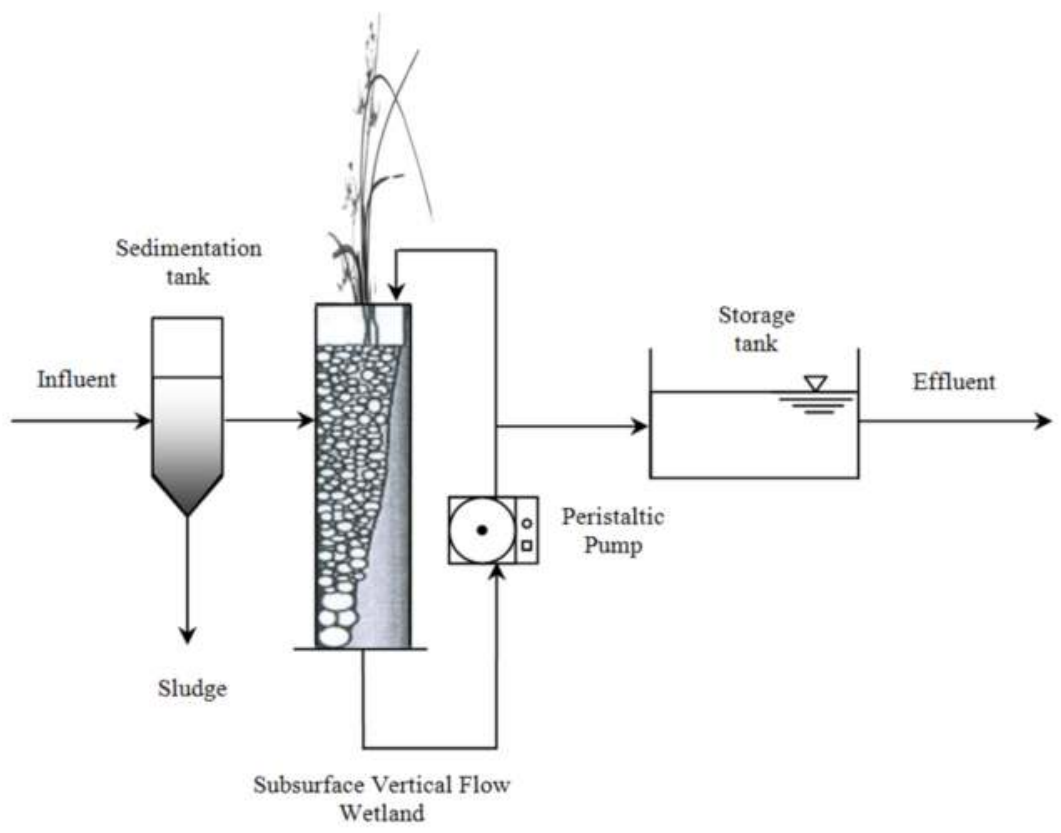

Figure 4. Flow diagram of the SSVFW

\section{- Lab-scale aerobic activated sludge reactor (ASR)}

ASR of $195 \mathrm{~mm}$ in diameter and $650 \mathrm{~mm}$ in height was used. The aeration system consisted of three diffusers, situated at the bottom of the bioreactor. The activated sludge (AS) was taken from a municipal wastewater treatment plant. After preliminary sedimentation in primary sedimentation tank the wastewater entered the ASR, where it was mixed with activated sludge in volume ratio 1:1. After reaching of the standard measurements of the controlled physicochemical characteristics, wastewater flow into secondary sedimentation tank for clarifying, which leading to removal of the suspended activated sludge (Fig. 5).

- hybrid installation consisted of an aerobic activated sludge reactor (ASR) and a subsurface vertical-flow wetland (ASR / SSVFW)

After preliminary sedimentationin primary sedimentation tank the wastewaterentered the ASR, where it was mixed with activated sludge in volume ratio 1:1. For several days the water is treated in the ASR to achieve a double reduce of pollutants concentration in terms of COD and $\left[\mathrm{NH}_{4}{ }^{+}-\right.$ $\mathrm{N}$ ]. After reaching the necessary concentration, the suspension passed through the secondary sedimentation tank for clarification and then entered the SSVFW for polishing (Fig. 6). The SSVFW was operated continuously in recirculation regime. The recirculation was employed at ratio of 1:1, giving SSVFW $1 \mathrm{~h}$ of wastewater-bed matrix contact and $1 \mathrm{~h}$ of effluent recirculation. The flow rate of the system was $80 \mathrm{ml} \mathrm{min}^{-1}$ and the hydraulic retention time was $0.9 \mathrm{~h}$. 


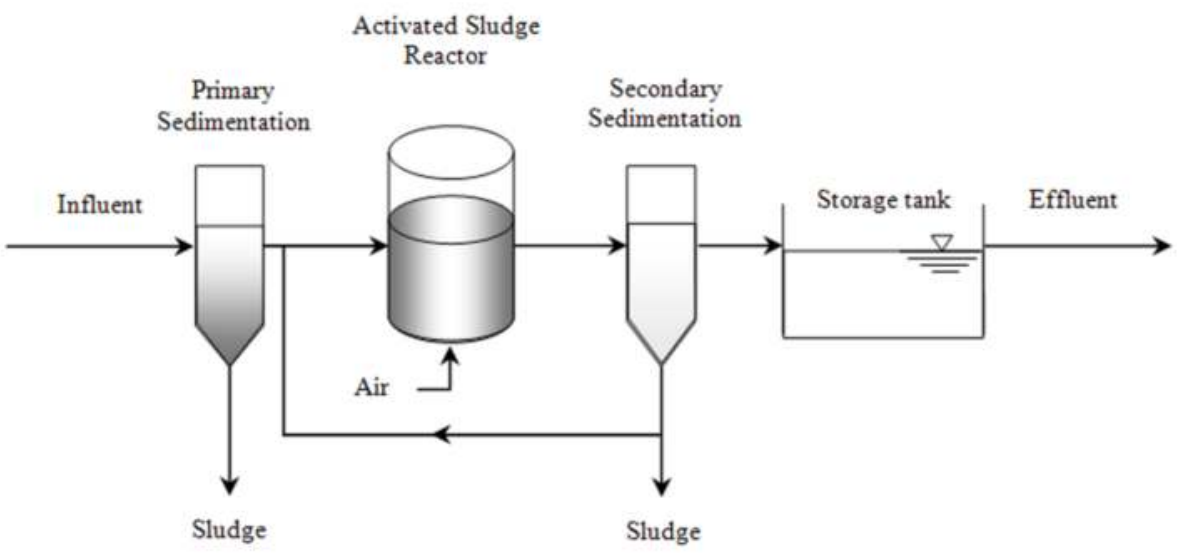

Figure 5. Flow diagram of the ASR

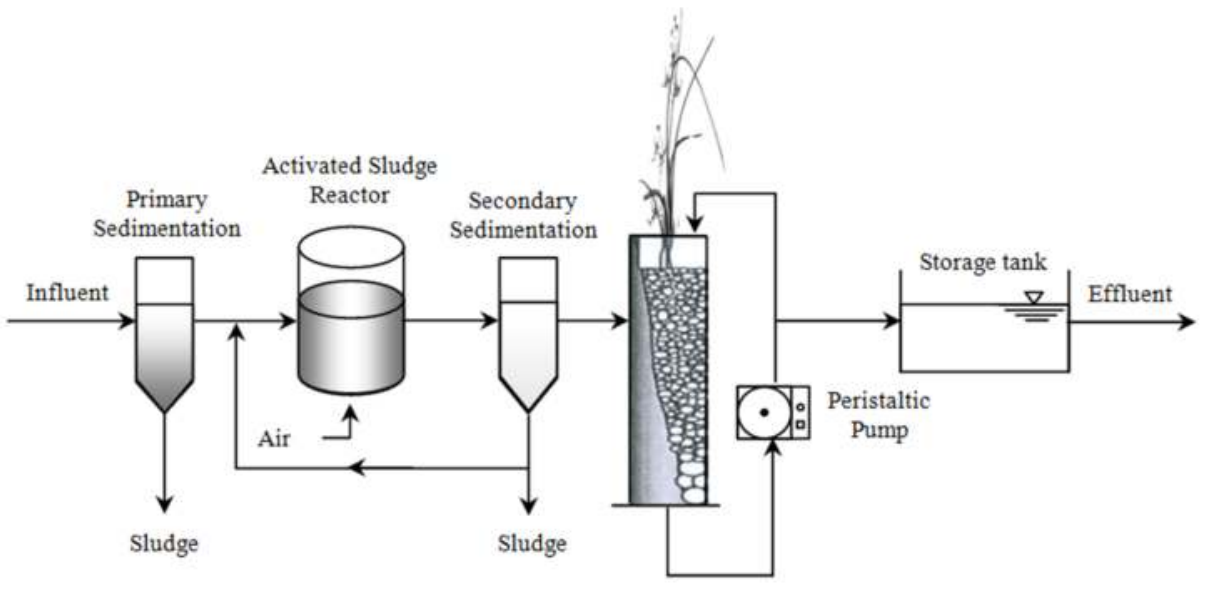

Subsurface Vertical Flow Wetland

Figure 6. Flow diagramme of the hybrid installation ASR-SSVFW

\section{Case study 1: Pig slurry treatment}

Fig. 7 to Fig. 10 illustrate the comparison of the water characteristics during the experiments. $\mathrm{COD}, \mathrm{BOD}$ and $\mathrm{NH}_{4}^{+}-\mathrm{N}$ values are presented as a proportion between their concentration in certain moment and its initial concentration $\left(\mathrm{COD}_{\mathrm{t}} / \mathrm{COD}_{0}, \mathrm{BOD}_{\mathrm{t}} / \mathrm{BOD}_{0}\right.$ and $\left.\mathrm{NH}_{4}{ }^{+}-\mathrm{N}_{\mathrm{t}} / \mathrm{NH}_{4}{ }^{+}-\mathrm{N}_{0}\right)$. 
During the first 3 days a significant decreasing of COD concentration was observed, especially in the ASR and in the hybrid installation ASR-SSVFW (fig. 7). This is a result of the additional aeration in the ASR. Until this moment the extent of COD decreasing in the ASR, SSVFW and hybrid installation ASR-SSVFW was: $58.9 \%, 39 \%$ and $49.8 \%$. After that the process slows down. During this period easierchemically oxidizableorganicmatterand biodegradableorganicmatter undergo changes under the influence of the oxygen and microbial activity. In the SSVFW the decreasing of the COD becomes slower because there is not additional aeration and the plants roots are the only suppliers of oxygen. During the first 3 days the COD concentration decreasing in the hybrid installation is almost identical with that in the ASR, but after wastewater inflow to the SSVFW of the hybrid installation, the tenor of the decreasing curve of the COD concentration lightly altered and reached that in the SSVFW. Due to the preliminary pig slurry dilution in the lab-scale including only subsurface vertical flow wetland, the initial concentrations of the analyzed parameters were almost twice lower than those in the other two experiments. That is why the water purification in the SSVFW is faster than that in the combined system. The reaching of the standards of measured physicochemical characteristic in the SSVFW, ASR and hybrid installation ASR-SSVFW becomes for twelve, then and sixteen days, respectively. Significant extent of the COD concentration decreasing in the three systems was achieved: in SSVFW - 93.1 $\%$, in ASR $96.7 \%$ and in hybrid installation ASR-SSVFW $97.1 \%$.

BOD decreasing in these systems becomes without significant differences and lightly in comparison with that of the COD decreasing (fig. 8). Under aeration BOD values in ASR and ASR-SSVFW, are decreasing a little bit fully in comparison with that in the SSVFW. During the first 3 days the decreasing extents of the BOD values in the three installations are: SSVFW - 43.3 $\%$, ASR $-61.8 \%$ and hybrid installation ASR-SSVFW - 54.2\%. The reaching of the standards in the SSVFW, ASR and ASR-SSVFW becomes for twelve, ten and sixteen days, respectively.

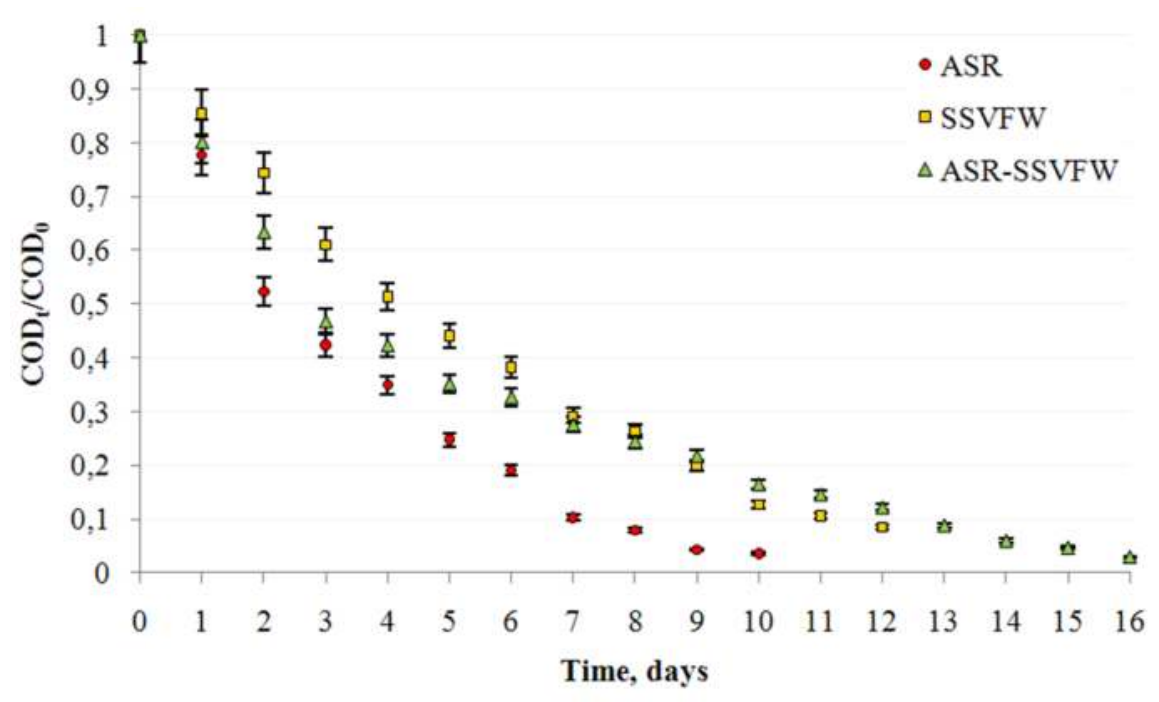

Figure 7. COD decreasing of the water samples in SSVFW, ASR and hybrid installation ASR-SSVFW 


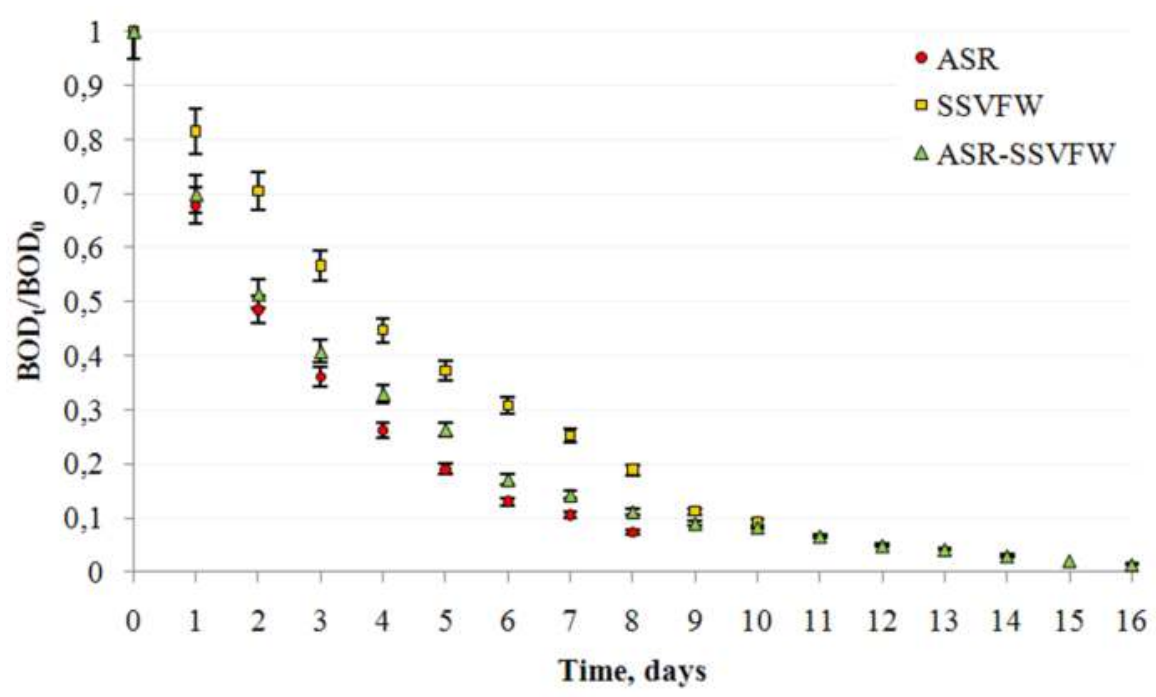

Figure 8. BOD decreasing of the water samples in SSVFW, ASR and hybrid installation ASR-SSVFW

The nitrogen is one of the main pollutants in wastewater that can cause eutrophication, affects dissolved oxygen levels of receiving water, and may cause toxicity (depending on the nitrogen form) to the aquatic organisms [83]. In these systems the transformation and removal of nitrogen are accomplished by both classical and newly discovered routes. The classical pathways include biological i.e. ammonification, nitrification, denitrification, plant uptake, biomass assimilation, dissimilatory nitrate reduction), and physicochemical routes (e.g. ammonia volatilization and adsorption). The newly discovered nitrogen removal routes are solely dependent on microbiological metabolism such as partial nitrification-denitrification.

The decreasing of ammonium - nitrogen in the systems is shown on Fig. 9. The similar effect was observed. During the first three days of the purification process in these three systems was observed elimination of significant part of the ammonium - nitrogen: SSVFW - $53.7 \%$, ASR $-100 \%$ and in the hybrid installation ASR-SSVFW - 93.7\%. This process is slower in the SSVFW because of insufficient oxygen concentration in the column matrix. Fully elimination of the ammonium - nitrogen in ASR was achieved for three days and for twelve days in the SSVFW. In the hybrid installation this was achieved for seven days. The decreasing of ammonium - nitrogen can be common result of volatilization, nitrification, plant uptake in wetland system and immobilization onto microbial cells. It is believed that nitrogen constitutes a major part of biomass, e.g. $12.4 \%$ of $\mathrm{C}_{5} \mathrm{H}_{7} \mathrm{O}_{2} \mathrm{~N}$ mass being nitrogen [84].

In parallel with the decreasing of ammonium-nitrogen concentration, an increasing of nitratenitrogen is observed, as a result of the nitrification (fig. 10). In the ASR that becomes faster in comparison with the process in the SSVFW and hybrid installation ASR-SSVFW. During the $5^{\text {th }}$ day was observed equalization of the nitrate-nitrogen concentration in the ASR and SSVFW. Elimination of the nitrate-nitrogen was not achieved during the wastewater purification in 
these systems. The reason for impossibility of nitrate-nitrogen removal is the lack of anoxic conditions in the systems. It is also well established that carbon availability plays an important role in both synthesis and activity of denitrifying enzymes as well as general support of the denitrifying population [85]. The lack of organic carbon source is supposed to keep insignificant denitrification. There are two required conditions for denitrification: anoxic environment and sufficient organic carbon source. In the ASR this process does not occur, because there is aeration. In constructed wetland system the bottom layer provides anoxic conditions for achieving a denitrification. Hence, initial high ammonium-nitrogen concentrations and deficient of organic carbon source were the reasons to depress the denitrification in the wetland system treated the pig wastewater.

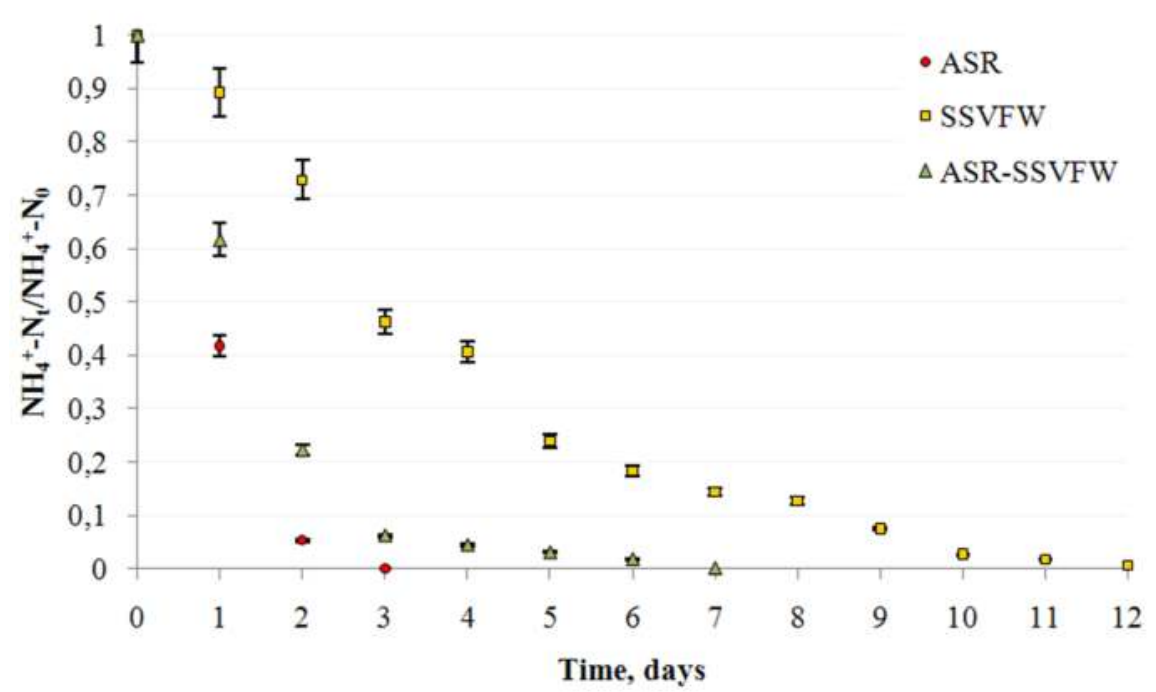

Figure 9. Ammonium-nitrogen in the water samples from SSVFW, ASR and hybrid installation ASR-SSVFW

During the first two days the odour of the treated wastewater in the systems was eliminated. The $\mathrm{pH}$ values of the wastewater are in the neutral zone $(6.3-8.3)$.

\section{Case study 2: Landfill leachate treatment}

Fig. 11 to Fig. 14 illustrate the comparison of the water characteristics during the experiments. $\mathrm{COD}, \mathrm{BOD}$ and $\mathrm{NH}_{4}{ }^{+}-\mathrm{N}$ values are presented like proportion between their concentration in certain moment and its initial concentration $\left(\mathrm{COD}_{\mathrm{t}} / \mathrm{COD}_{0}, \mathrm{BOD}_{\mathrm{t}} / \mathrm{BOD}_{0}\right.$ and $\left.\mathrm{NH}_{4}{ }^{+}-\mathrm{N}_{\mathrm{t}} / \mathrm{NH}_{4}{ }^{+}-\mathrm{N}_{0}\right)$.

During the experiments the COD decreasing in these three systems is similar (fig. 11). The reduction of the COD was slightly faster with the preliminary aerobic treatment of the landfill leachate. During the first three days there was a significant decrease of COD. The removal 


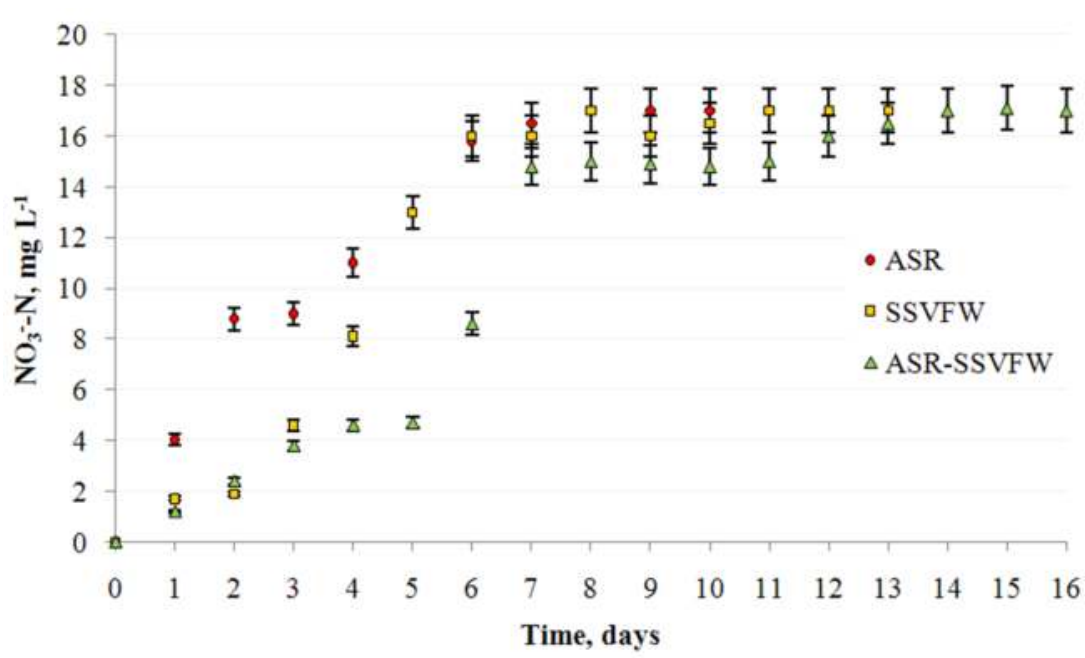

Figure 10. Nitrate-nitrogen in the water samples from SSVFW, ASR and integrated installation ASR-SSVFW

efficiency in the landfill leachate on the third day in the SSVFW is $24 \%$, in the ASR it is $51.5 \%$ and in the hybrid system ASR-SSVFW it is $51 \%$. The COD reduction is smooth and without significant fluctuations. The limit concentration of COD in the SSVFW was reached for 15 days, in the ASR for 9 days and in the hybrid installation ASR-SSVFW for 12 days. The removal efficiency is $98 \%, 97.8 \%$ and $97.9 \%$, respectively.

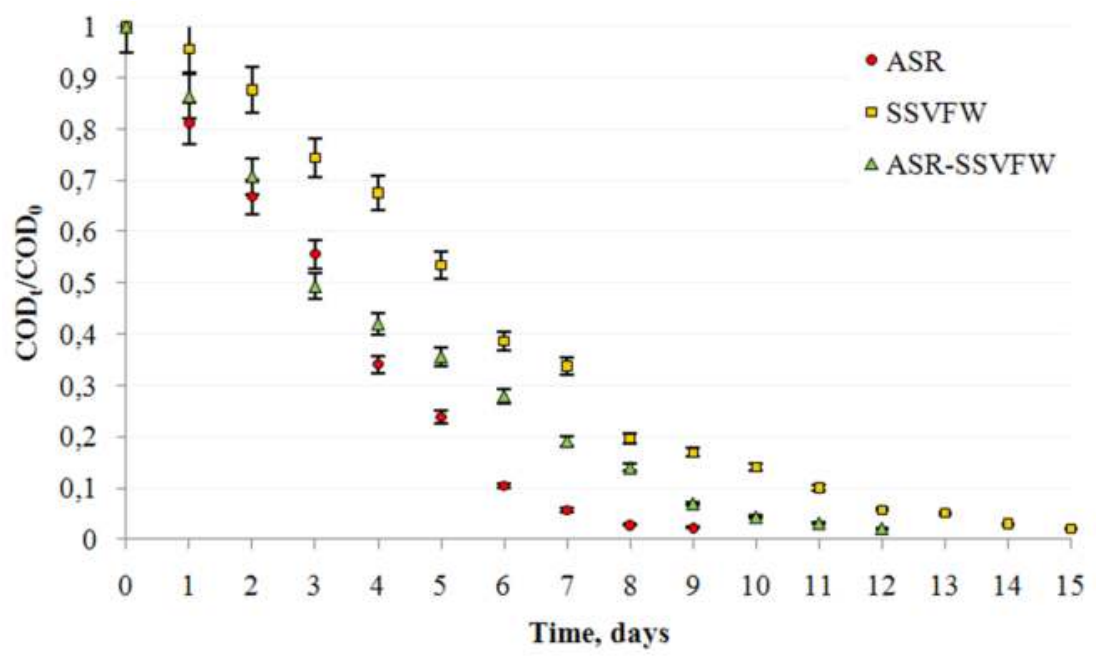

Figure 11. COD decreasing of the water samples in SSVFW, ASR and hybrid installation ASR-SSVFW 
The preliminary dilution with tap water of the landfill leachate and the flowing into the SSVFW, lead to almost double decrease of the BOD. BOD decreasing in the wetland system is smoother compared to the ASR and the hybrid installation (fig. 12). The removal efficiency during the first three days is $46.8 \%$ in the SSVFW, $72.2 \%$ in the ASR and $71.4 \%$ in the hybrid installation ASR-SSVFW. The limiting concentration for BOD in the SSVFW was achieved in 11 days with $92.9 \%$ removal efficiency, in the ASR - 6 days with $95.4 \%$ removal efficiency and in the ASR-SSVFW respectively in 9 days with $94.5 \%$ removal efficiency.

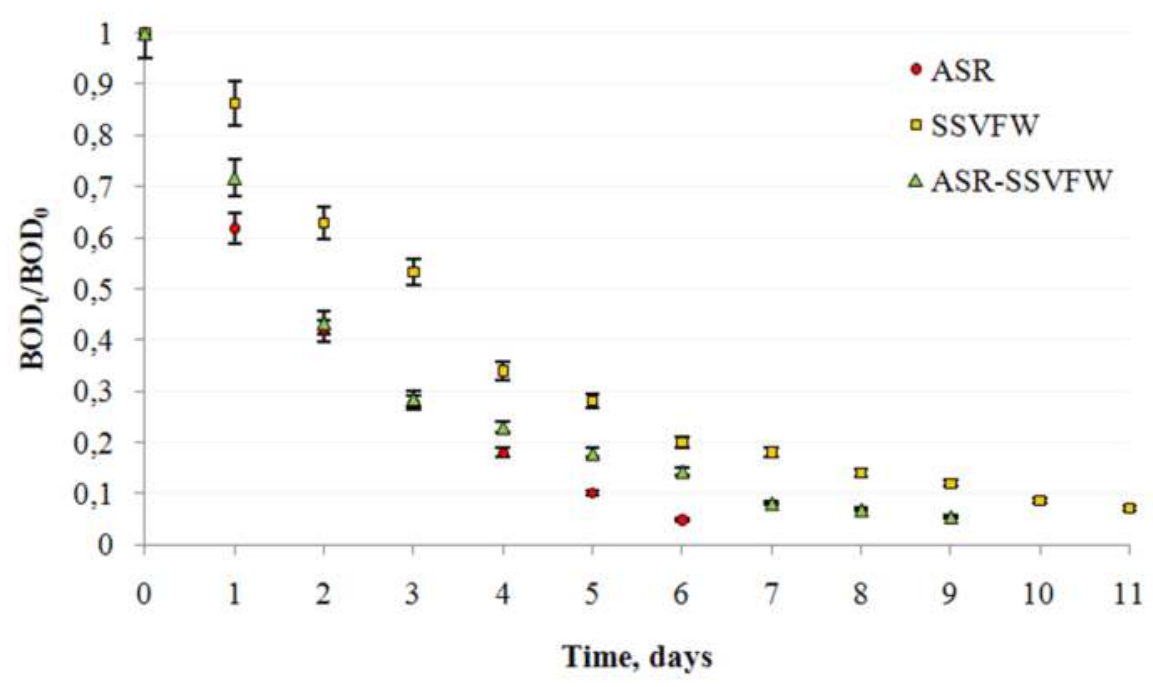

Figure 12. BOD decreasing of the water samples in SSVFW, ASR and hybrid installation ASR-SSVFW

The preliminary dilution of the wastewater and the flowing into the SSVFW, resulted in double decrease of the concentration of the $\left[\mathrm{NH}_{4}{ }^{+} \mathrm{-N}\right]$. As shown on Fig. 13 a sharp decrease of the $\left[\mathrm{NH}_{4}{ }^{+} \mathrm{N}\right]$ concentration in the first three days occurs in the systems where preliminary aerobic treatment of the landfill leachate was used. The removal efficiency in the SSVFW is $74.8 \%$, in the ASR $99.6 \%$ and in the ASR-SSVFW 96.2\%. This is probably due to the air blowing into the aerobic reactor to support microbial activity. On the other hand this intensive aeration can cause the escape of ammonia from the system.

Complete removal of the $\left[\mathrm{NH}_{4}{ }^{+}-\mathrm{N}\right]$ in the SSVFW was achieved for 10 days while in the ASR it was for 4 days and in the ASR-SSVFW - for 5 days. This can be explained by the fact that in this reactor the oxygen is not enough for the nitrification and from the constructive point of view the separation of ammonia from the system is embarrassed.

The aerobic treatment of the landfill leachate in the reactor with suspended activated sludge results in a significant accumulation of nitrate ions in comparison with the process taking place in the wetland system where preliminary diluted landfill leachate is treated (Fig. 14). In the laboratory systems an accumulation of the nitrate ions was observed. Probably this effect is 


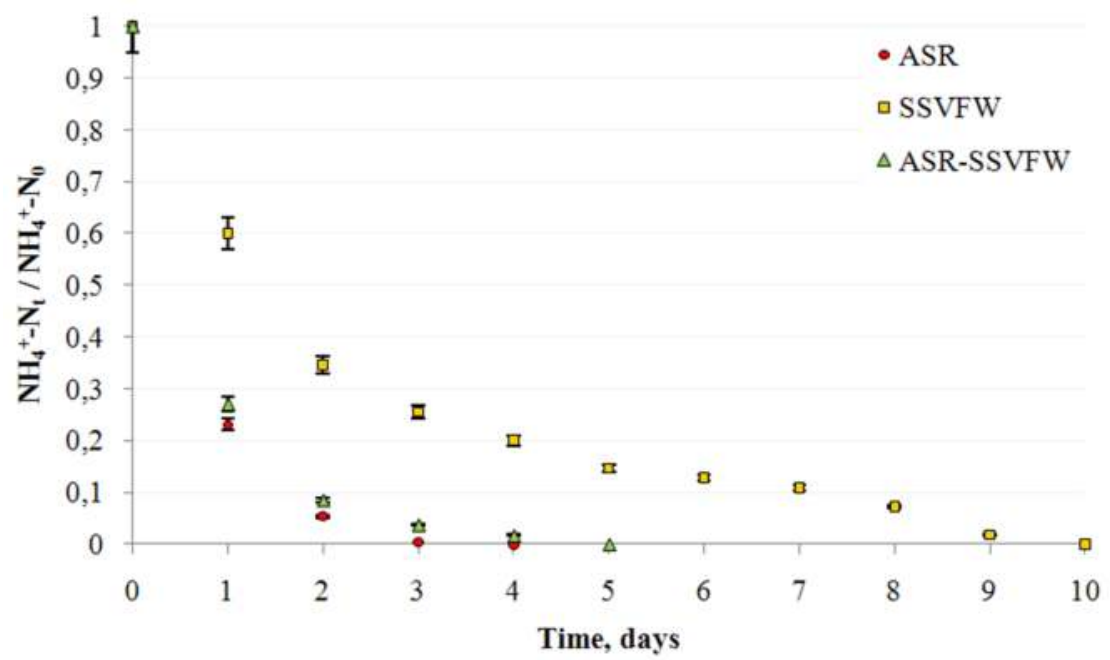

Figure 13. $\mathrm{NH}_{4}{ }^{+} \mathrm{N}$ decreasing in the water samples from SSVFW, ASR and hybrid installation ASR-SSVFW

due to the insufficient quantity of the source of organic carbon in the wetland system [85] and on the other hand - the aerobic conditions in the aerobic bioreactor.

During the experiments $\mathrm{pH}$ decreased slightly from 8,3 to 7,5 . The neutralization of the landfill leachate was achieved during the preliminary dilution with tap water, while in the hybrid installation it was achieved during the third day of operation.

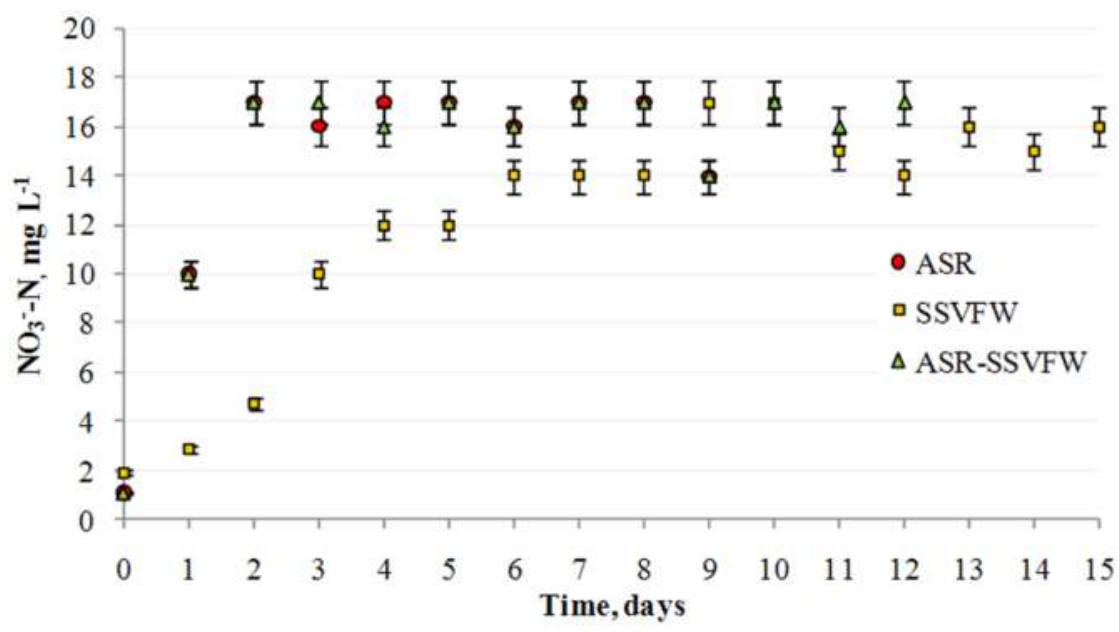

Figure 14. $\left[\mathrm{NO}_{3}{ }^{-}-\mathrm{N}\right]$ decreasing of the water samples in SSVFW, ASR and hybrid installation ASR-SSVFW 
In Table 2 are compared the data characterized the two studied wastewaters that are treated in ASR, SSVFW and hybrid installation ASR-SSVFW. The data are compared with the standards in Bulgaria (Benchmarks). Obviously, the requirements of the national standards were met.

\begin{tabular}{|c|c|c|c|c|c|c|c|c|c|c|c|c|c|c|c|c|}
\hline \multirow{3}{*}{$\begin{array}{c}\text { Paramet } \\
\text { er }\end{array}$} & \multicolumn{2}{|c|}{ Influent } & \multicolumn{6}{|c|}{ Effluent } & \multirow[t]{3}{*}{$\begin{array}{l}\text { Bench } \\
\text { marks }\end{array}$} & \multirow{3}{*}{$\begin{array}{c}\text { Average } \\
\text { efficiency, } \\
\%\end{array}$} & \multicolumn{6}{|c|}{ Time, days } \\
\hline & & & \multicolumn{2}{|c|}{ ASR } & \multicolumn{2}{|c|}{ SSVFW } & \multicolumn{2}{|c|}{ ASR-SSVFW } & & & \multicolumn{2}{|c|}{ ASR } & \multicolumn{2}{|c|}{ SSVFW } & \multicolumn{2}{|c|}{$\begin{array}{l}\text { ASR- } \\
\text { SSVFW }\end{array}$} \\
\hline & $\begin{array}{l}\frac{B}{3} \\
\frac{5}{n} \\
\frac{0}{0}\end{array}$ & 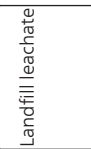 & $\begin{array}{l}\frac{3}{3} \\
\frac{\bar{n}}{n} \\
\frac{.0}{2}\end{array}$ & 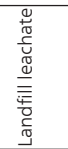 & $\begin{array}{l}\frac{3}{5} \\
\frac{0}{2} \\
\frac{0}{2}\end{array}$ & 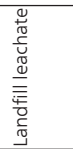 & $\begin{array}{l}\frac{3}{3} \\
\frac{3}{5} \\
\frac{0}{2}\end{array}$ & 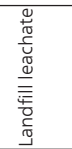 & & & $\frac{3}{\frac{3}{5}}$ & 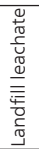 & $\begin{array}{l}\frac{3}{5} \\
\frac{5}{0} \\
\frac{0}{2}\end{array}$ & 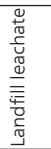 & $\begin{array}{l}\frac{Z}{5} \\
\frac{3}{n} \\
\frac{0}{2}\end{array}$ & 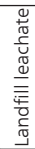 \\
\hline $\begin{array}{c}\text { COD, mg } \\
\mathrm{L}^{-1}\end{array}$ & $\begin{array}{c}1535 \pm \\
502\end{array}$ & $\begin{array}{c}2940 \pm \\
140\end{array}$ & $\begin{array}{c}72.4 \pm \\
7.1\end{array}$ & $69 \pm 1$ & $\begin{array}{c}69.3 \pm \\
3.9\end{array}$ & $\begin{array}{c}67.5 \pm \\
11.5\end{array}$ & $\begin{array}{l}63.6 \\
\pm 4\end{array}$ & $\begin{array}{c}62.5 \pm \\
4.5\end{array}$ & 70 & 95.6 & 11 & 12 & 12 & 16 & 10 & 12 \\
\hline $\begin{array}{c}\text { BOD, mg } \\
L^{-1}\end{array}$ & $\begin{array}{c}612 \pm \\
419\end{array}$ & $\begin{array}{c}230.5 \pm \\
26.5\end{array}$ & $\begin{array}{c}14.4 \pm \\
0.4\end{array}$ & $\begin{array}{c}15.6 \pm \\
0.7\end{array}$ & $\begin{array}{c}15.7 \pm \\
1.5\end{array}$ & $\begin{array}{c}14.5 \pm \\
0.5\end{array}$ & $\begin{array}{r}15.8 \\
\pm 0.4\end{array}$ & $\begin{array}{c}15.7 \pm \\
0.8\end{array}$ & 15 & 97.5 & 9 & 10 & 10 & 9 & 9 & 11 \\
\hline $\begin{array}{c}\mathrm{NH}_{4}{ }^{+}-\mathrm{N} \\
\mathrm{mg} \mathrm{L}^{-1}\end{array}$ & $322 \pm 87$ & $\begin{array}{c}206.7 \pm \\
8.3\end{array}$ & 0 & 0 & 0 & 0 & 0 & 0 & 2 & 100 & 7 & 6 & 10 & 10 & 8 & 8 \\
\hline $\begin{array}{c}\mathrm{NO}_{3}{ }^{-}-\mathrm{N} \\
\mathrm{mg} \mathrm{L}^{-1}\end{array}$ & 0 & $1.5 \pm 0.4$ & $\begin{array}{c}16.7 \pm \\
0.3\end{array}$ & $\begin{array}{c}16.5 \pm \\
0.5\end{array}$ & $\begin{array}{c}16.9 \pm \\
0.1\end{array}$ & $\begin{array}{l}17 \pm \\
0.1\end{array}$ & $\begin{array}{r}15.9 \\
\pm 0.6\end{array}$ & $\begin{array}{c}17 \pm \\
0.1\end{array}$ & 10 & - & - & - & - & - & - & - \\
\hline $\mathrm{pH}$ & $7.2 \pm 1.1$ & $7.9 \pm 0.4$ & $\begin{array}{c}7.1 \pm \\
0.1\end{array}$ & $\begin{array}{c}7.2 \pm \\
0.1\end{array}$ & $\begin{array}{c}7.2 \pm \\
0.1\end{array}$ & $\begin{array}{c}7.2 \pm \\
0.1\end{array}$ & $\begin{array}{c}7.1 \pm \\
0.1\end{array}$ & $7 \pm 0.1$ & $6.0-8.5$ & & & & & & & \\
\hline
\end{tabular}

Table 2. Characteristics of the influent and the effluents from the three systems

The flow rate is one of the important factors, which control the performance of subsurface vertical flow wetland systems. The higher flow rate promotes faster passage of wastewater through the media, thus reducing the optimum contact time and leads to longer period needed for treatment [74]. The recirculation of the treated wastewater through the subsurface verticalflow wetland also has a significant role in the purification efficiency [74, 87-88]. For confirmation of these statements experiments with three different wastewater flow rates $(40,60$ and 82 $\mathrm{ml} / \mathrm{min}$ ) and three different recirculation ratios (1:1, 1:2 and 1:3) were conducted. The hydraulic retention time in the wetland system was $1.8,1.2$ and $0.9 \mathrm{~h}$, respectively.

The comparison of the COD and BOD values of the treated landfill leachate during the experiments is illustrated in fig.15. The data demonstrate the influence of the recirculation at the three different flow rates on the treatment ability of the lab-scale vertical-flow wetland system. The decreasing of COD values after five days from the beginning is fast. Then the process slows down. The efficiency at the $5^{\text {th }}$ day (recirculation ratio $1: 1$ ) was $67 \%$ at flow rate $82 \mathrm{ml} \mathrm{min}-1,81 \%$ - at flow rate $60 \mathrm{ml} \mathrm{min}^{-1}$ and $90 \%$ - at flow rate $40 \mathrm{ml} \mathrm{min}{ }^{-1}$. The efficiency at recirculation ratio $1: 2$ was $78 \%, 86 \%$ and $90 \%$, respectively, and at recirculation ratio 1:3 it was $78 \%, 90 \%$ and $96 \%$, respectively. COD decreased slower when the flow rate was higher. 
The elimination of BOD occurs fast in most cases during the initial five days. The efficiency of BOD removal at recirculation ratio 1:1 was $72 \%, 85 \%$ and $92 \%$ for flow rate $82 \mathrm{ml} \mathrm{min}^{-1}, 60$ $\mathrm{ml} \mathrm{min}-1$ and $40 \mathrm{ml} \mathrm{min}^{-1}$, respectively. At recirculation ratio $1: 2$ it was $83 \%, 92 \%$ and $93 \%$ for the corresponding flow rates. The efficiency was $91 \%$ at flow rate $82 \mathrm{ml} \mathrm{min}^{-1}$ and recirculation ratio1:3. The same efficiency was obtained after 4 days at flow rate $60 \mathrm{ml} \mathrm{min}^{-1}$ and after 3 days at flow rate $40 \mathrm{ml} \mathrm{min}^{-1}$. It was observed that the longer the water remained quiet in SSVFW, the faster COD and BOD decreased.
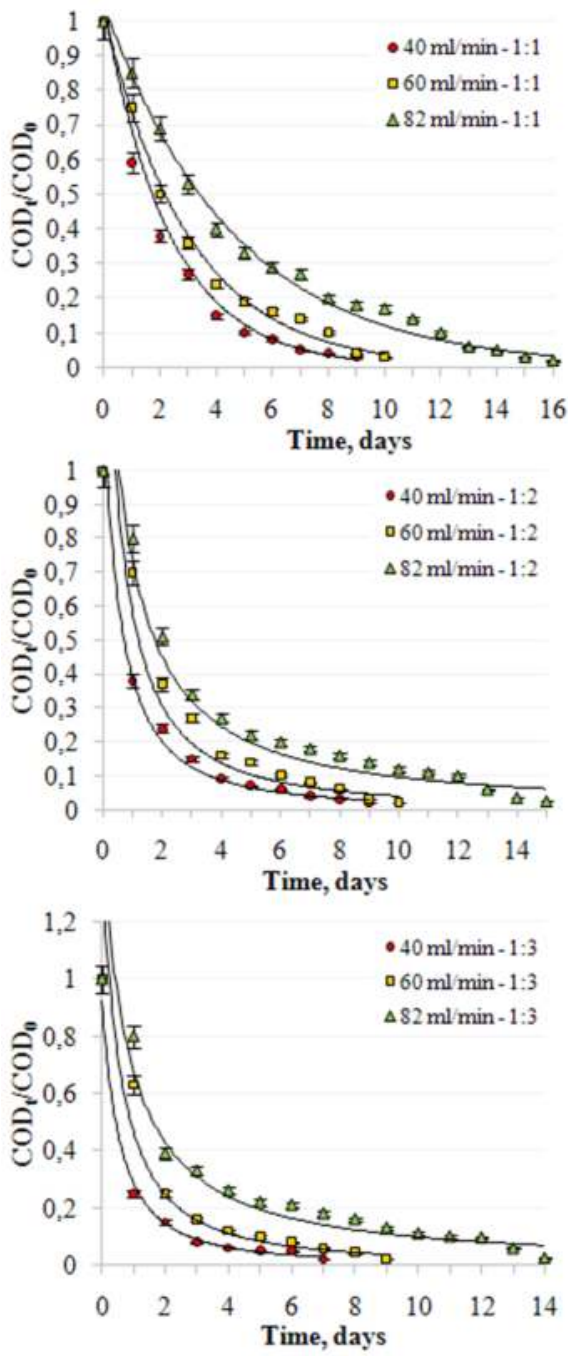
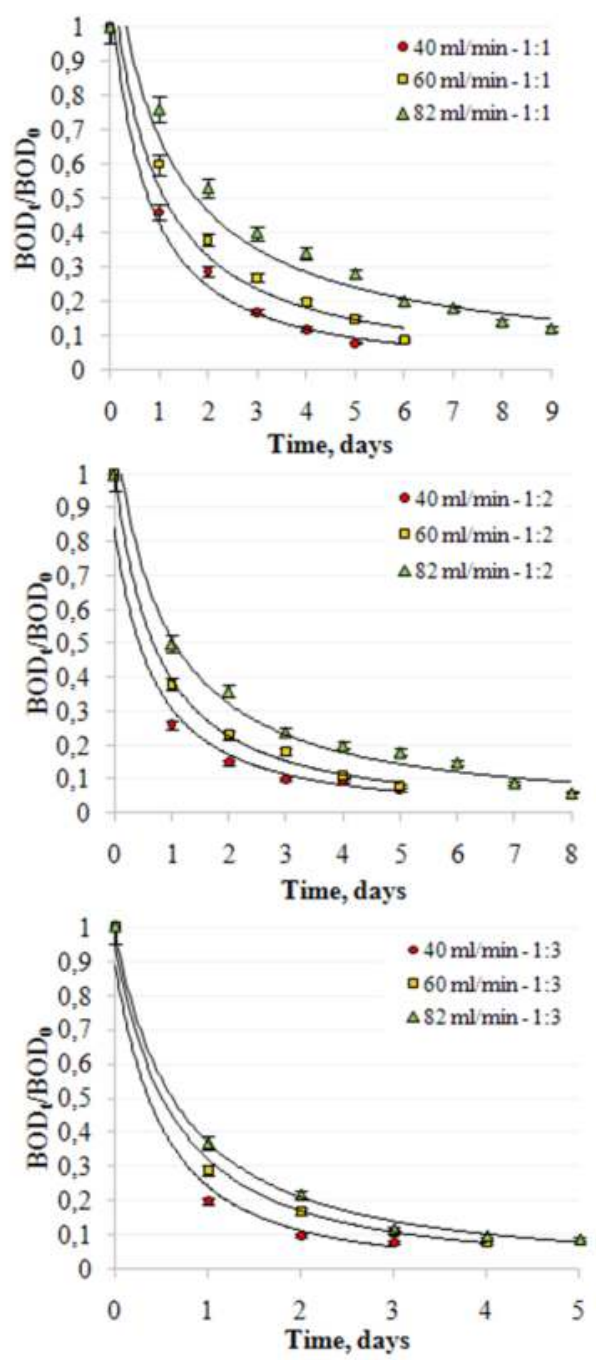

Figure 15. Comparison of the COD and BOD values of the treated landfill leachate at different flow rates 

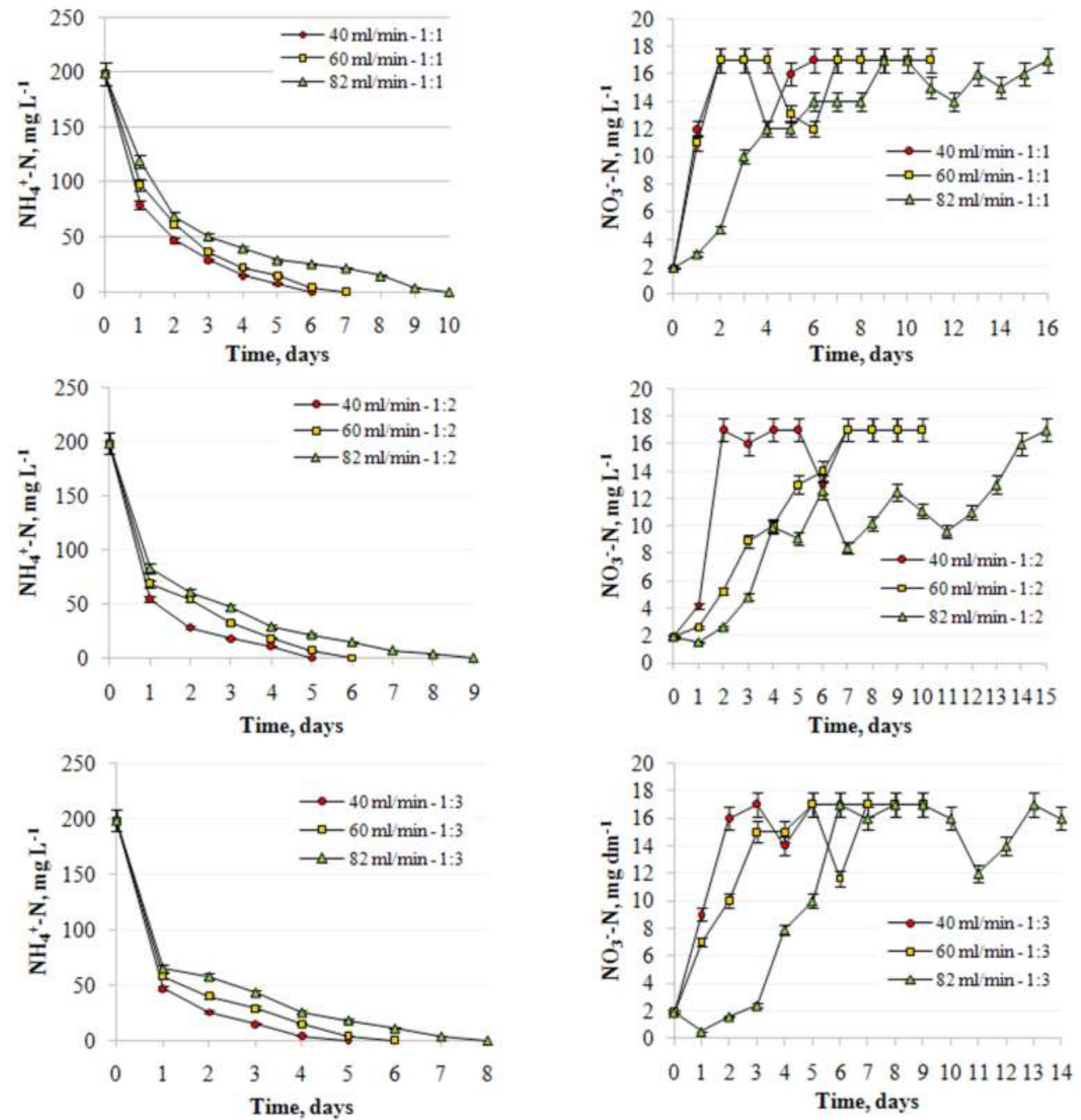

Figure 16. Comparison of the $\left[\mathrm{NH}_{4}{ }^{+}-\mathrm{N}\right]$ and $\left[\mathrm{NO}_{3}{ }^{-} \mathrm{N}\right]$ values of the treated landfill leachate at different flow rates

The importance of nitrogen removal is comparable with that for organic carbon, toxic compounds and metals removal during the leachate treatment in SSVFW. Ammonium removal by nitrification in constructed wetlands differing in design and purpose was reported [89]. It is known that autotrophic nitrification consists of two successive aerobic reactions, the conversion of ammonium to nitrite by ammonium oxidizing bacteria and the conversion of nitrite to nitrate by nitrite oxidizing bacteria. The concentration of ammonium-nitrogen in the influent used in this study was relatively high. So, it was interesting to record the changes of $\mathrm{NH}_{4}{ }^{+} \mathrm{N}$ and $\mathrm{NO}_{3}-\mathrm{N}$ values during the leachate treatment at different flow rates and recirculation ratios. 
The influence of these parameters on the ammonium depletion is illustrated in Fig. 16. It was exhausted completely during the experiments. The decrease of ammonium-nitrogen could be collective result of volatilization, nitrification, plant uptake in wetland system and immobilization. At the same time $\mathrm{NO}_{3}^{-}-\mathrm{N}$ increased depending on the flow rate and the recirculation ratios. In all cases the values increased during the first 1-2 days. After this period the curves shape depended on the experimental conditions. The concentration of $\mathrm{NO}_{3}^{-}-\mathrm{N}$ has increased faster when the flow rate was lower. The influence of the recirculation ratios was opposite. During the experiments at different conditions dissolved oxygen was measured and the values were from 5.2 to $8 \mathrm{mg} \mathrm{L}^{-1}$. It is known that the concentration of $1 \mathrm{mg} \mathrm{L}^{-1}$ is sufficient for oxidation of ammonium [90].

The lack of the denitrification during the treatment can be a result of the less activity of denitrifying bacteria in the system. Vymazal reported that SSVFW removes successfully $\mathrm{NH}_{4}{ }^{+}-\mathrm{N}$ but the denitrification is very limited in these systems [91]. It was also well established that carbon availability plays an important role in both synthesis and activity of denitrifying enzymes as well as general support of the denitrifying population. The lack of organic carbon sources is thought to prevent significant levels of denitrification [85].

Phosphorus removal in wetland treatment systems occurs through adsorption, plant uptake, complexation, and precipitation [92]. The value of total phosphorus (TP) in the treated leachate was relatively low $\left(5.5 \mathrm{mg} \mathrm{L}^{-1}\right)$. It was established that TP removal follows the same tendency as $\mathrm{NH}_{4}{ }^{+} \mathrm{N}$ removal. During the first two days a significant TP elimination occured (Fig.17). The higher flow rate leads to a longer period of elimination of TP. At the same time the change of the recirculation ratio from 1:1 to 1:3 (water stays quiet in SSVFW longer) leads to shorter period of elimination (e.g. at flow rate $82 \mathrm{ml} \mathrm{min}^{-1}$ the TP removal was $41.8 \%, 60 \%$ and 67.3 $\%$ for 1:1, 1:2 and 1:3 recirculation ratios during 8,6 and 4 days, correspondingly).

It was established that during the experiments with different flow rate and hydraulic retention time pH slightly decreased from 7.9 to 7.5 and the salinity also decreased from 2.5 to $1.9 \%$. TDS gradually decreased from 2460 to $1778 \mathrm{mg} \mathrm{L}^{-1}$. The values of TSS varied from 1.91 to 3.96 $\mathrm{g} \mathrm{L}^{-1}$. Landfill leachate conductivity decreased from 4710 to $3408 \mu \mathrm{S} \mathrm{cm} \mathrm{c}^{-1}$. TDS, TSS, salinity, phosphorus concentration as well as the conductivity have been determined only for the case of landfill leachate at different flow rate and hydraulic retention time.

It is well known that the vegetation in the wetland systems play a significant role in purification process. Aquatic plants enhance nutrient removal through biomass accumulation, fixation of inorganic and organic particles and where ammonium-N is present, by the creation of an oxidized rhizosphere [93]. In the absence of plants, the gravel substrate provided significant wastewater treatment $[94,95]$, although most studies report improved nutrient removal where plants are present [96]. Our experiments without vegetation in the lab-scale subsurface vertical-flow wetland system leads to lower treatment efficiency in comparison whit that where in the laboratory system has grown vegetation (Fig. 18). That confirms the important role of the plants in purification process. On the other hand the lack of plants allows the use of additional organic carbon source, which achieves a denitrification process (Fig. 19). In these experiment was added methanol in the SSVFW without vegetation. As a result was observed decreasing of the nutrition elements and their elimination from the system. 

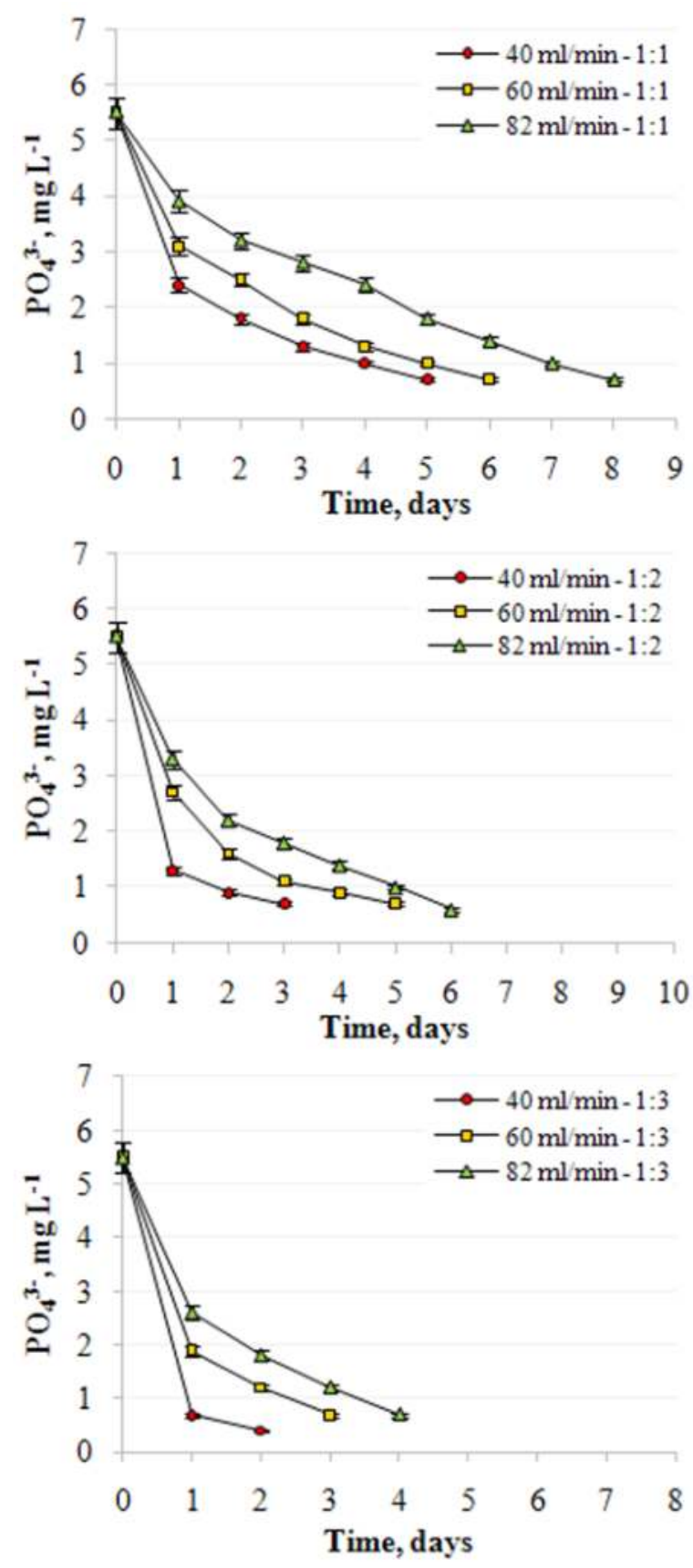

Figure 17. Comparison of the $\left[\mathrm{PO}_{4}{ }^{3-}\right]$ values of the treated landfill leachate at different flow rates 


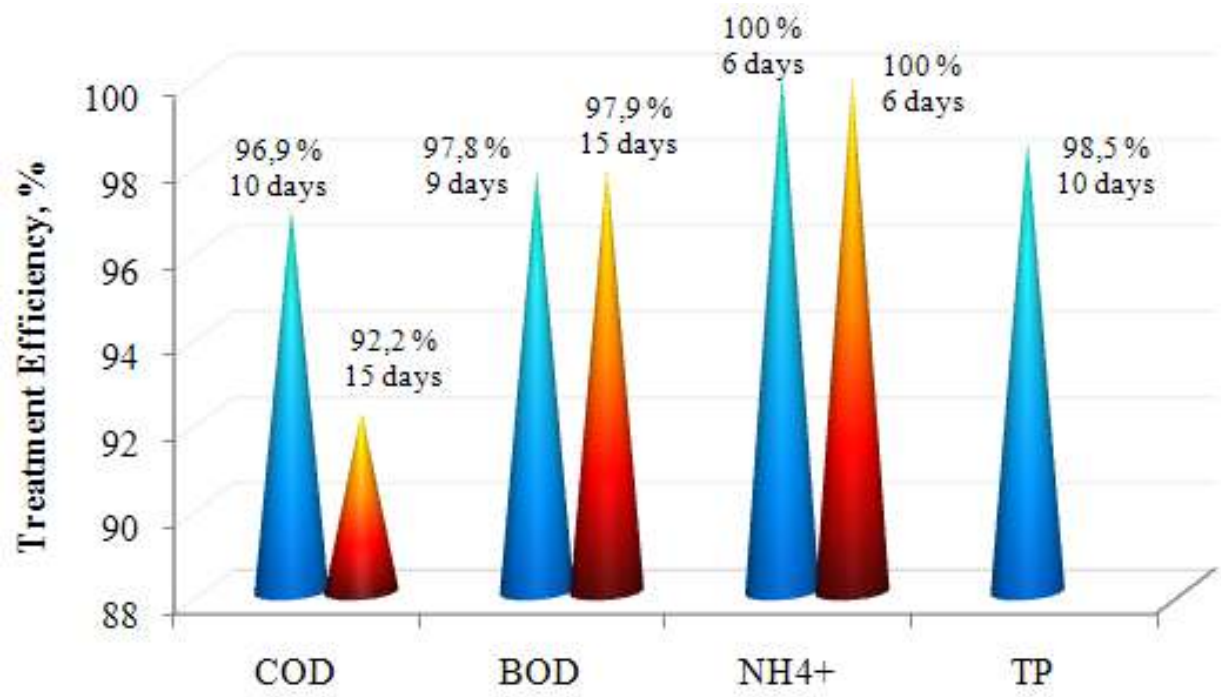

Ewith Phragmites australis = without Phragmites asutralis

Figure 18. Treatment efficiency during the experiments with/without Phragmites australis

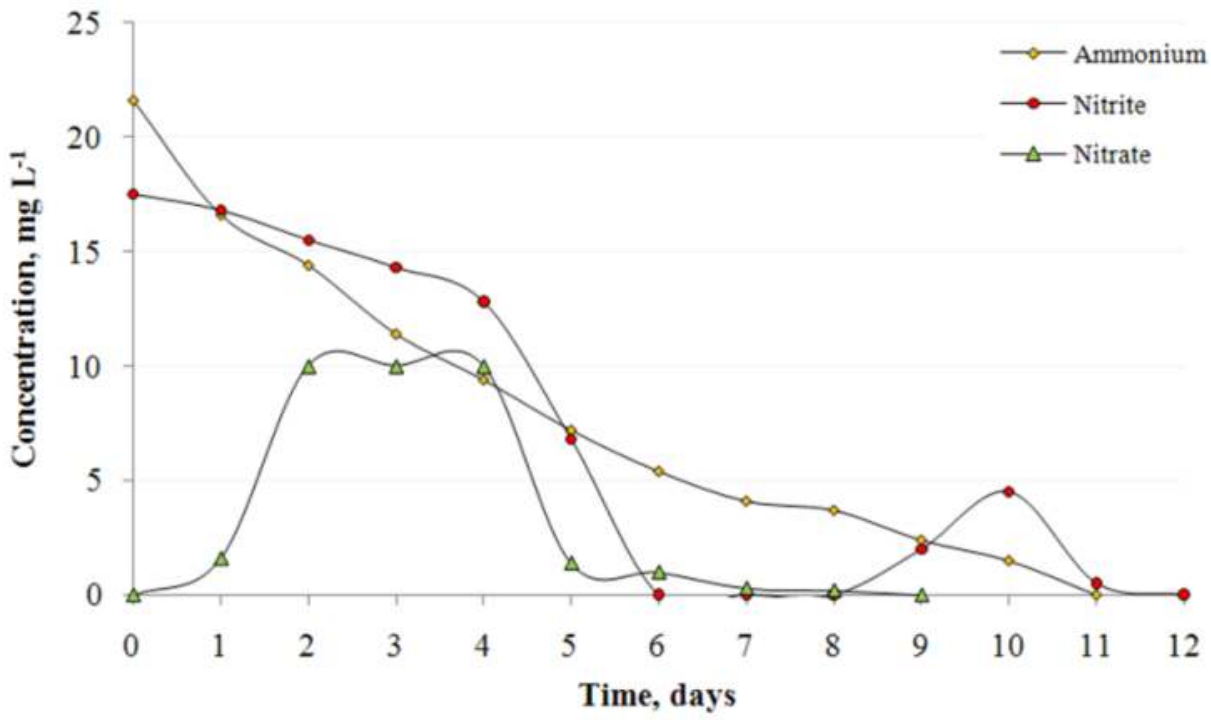

Figure 19. Nutrition concentration decreasing with applying of additional carbon source 


\section{Conclusions}

Activated sludge reactor, susbsurface vertical-flow wetland and hybrid installation were studied for aerobic treatment and polishing of two types wastewater - pig slurry and landfill leachate. It was established that the values of the treated water characteristics significantly decreased for comparatively short time accompanied by odour elimination and neutralization of wastewater. Significant COD and BOD decreasing were attained in those cases and the aquatic standards were met. Fully elimination of the ammonium-nitrogen in the SSVFW was achieved for longer period of time in comparison whit that in the ASR. Decreasing of obtained nitrate-nitrogen was not achieved in the SSVFW with growing Phragmites australis because of absence of anoxic conditions and probably of insufficient organic carbon source. In the SSVFW without vegetation was achieved denitrification process. It was established that the higher flow rate leads to longer period needed for treatment. The recirculation ratios also influence the purification process. Alternating between water movement through the SSVFW and stagnant periods resulted in a varying extent of purification, and the longer the stagnant period of the water in SSVFW the shorter the period for obtaining the desired characteristics of the effluent water was. These investigations show that the use of SSVFW is also effective as ASR and combination of the processes accelerate the purification process. The SSVFW has some advantages simulating the processes occurring in the natural wetlands, easy maintenance, energy conservation and cost effectiveness.

\section{Nomenclature}

AS - Activated Sludge

ASR - Aerobic Sludge Reactor

ASR-SSVFW - Aerobic Sludge Reactor - Subsurface Vertical-Flow Wetland (hybrid installation)

BOD - Biochemical Oxygen Demand

COD - Chemical Oxygen Demand

CW - Constructed Wetland

DO - Dissolved Oxygen

LCA - Life Cycle Assessment

$\mathrm{NH}_{4}{ }^{+} \mathrm{N}-\mathrm{Ammonium}$ Nitrogen

$\mathrm{NO}_{2}^{-}-\mathrm{N}$ - Nitrite Nitrogen

$\mathrm{NO}_{3}^{-}-\mathrm{N}$ - Nitrate Nitrogen

$\mathrm{PO}_{4}{ }^{3-}-\mathrm{P}$ - Phosphates 
SSVFW - Subsurface Vertical Flow Wetland

TKN - Total Kjehldahl Nitrogen

TN - Total Nitrogen

TP - Total Phosphorus

TSS - Total Suspended Solids

VF - Vertical Flow

\section{Author details}

Silviya Lavrova and Bogdana Koumanova*

*Address all correspondence to: bkk@uctm.edu

University of Chemical Technology and Metallurgy, Sofia, Bulgaria

\section{References}

[1] Reed, S, \& Brown, D. Constructed Wetland Design- The First Generation, Water Environment Research (1992). , 64, 776-81.

[2] Technical/Regulatory GuidelineTechnical and Regulatory Guidance Document for Constructed Treatment Wetlands. The Interstate Technology and Regulatory Council Wetlands Team December; (2003).

[3] Kadlec, R, \& Knihght, R. Treatment wetlands. Lewis Publishers; (1996).

[4] Moshiri, G. Constructed Wetlands for Water Quality Improvement. Lewis Publishers, Boca Raton; (1993).

[5] Cooper, P, Smith, M, \& Maynard, H. The Design and Performance of a Nitrifying Vertical Flow Reed Bed Treatment System. Water Science and Technology (1996). , 35, 215-221.

[6] Haberl, R. Constructed Wetlands: A Chance to Solve Wastewater Problems in Developing Countries. Water Science and Technology (1999). , 40, 11-17.

[7] Vymazal, J. Types of Constructed Wetlands for Wastewater Treatment: Their Potential for Nutrient Removal, In: Vymazal J. (ed.) Transformations of Nutrients in Natural and Constructed Wetlands. Backhuys Publishers; (2001). , 1-93. 
[8] Vymazal, J. Constructed Wetlands for Wastewater Treatment in Europe, In: Dunne EJ, Reddy R, Carton OT (ed.) Nutrient Management in Agricultural Watersheds: a Wetland Solution. Wageningen Academic Publishers; (2005a). , 230-244.

[9] Vymazal, J. Horizontal Sub-Surface Flow and Hybrid Constructed Wetlands Systems for Wastewater Treatment. Ecological Engineering (2005b). , 25, 478-490.

[10] Van de Moortel ARousseau D., Tack F., Pauw N. A Comparative Study of Surface and Subsurface Flow Constructed Wetlands for Treatment of Combined Sewer Overflows: a Greenhouse Experiment. Ecological Engineering (2009). , 35(2), 175-183.

[11] Tuszynska, A, \& Obarska-pempkowiak, H. Dependence Between Quality and Removal Effectiveness of Organic Matter in Hybrid Constructed Wetlands. Bioresource and Technology (2008). , 99, 6010-6016.

[12] Aslam, M, Murtaza, M, Baig, M, Qazi, I, \& Iqbal, J. Treatment Performances of Compost-Based and Gravel-Based Vertical Flow Wetlands Operated Identically for Refinary Wastewater Treatment in Pakistan. Ecological Engineering (2007). , 30, 34-42.

[13] Korkusuz, E. A. Treatment Efficiencies of the Vertical Flow Pilot-Scale Constructed Wetlands for Domestic Wastewater Treatment. Turkish Journal of Engineering and Environmental Sciences (2004). , 28, 333-344.

[14] Ongnext, S, Uchiyama, K, Inadama, D, \& Yamagiwa, K. Simultaneous removal of color, organic compounds and nutrients in azo dye-containing wastewater using upflow constructed wetland. Journal of Hazardous Materials (2009).

[15] Davies, L, Pedro, J, Novais, J, \& Martins-dias, S. Aerobic Degradation of Acid Orange 7 in a Vertical-Flow Constructed Wetland. Water research (2006). , 40, 2055-2063.

[16] Zhang, D, Gersberg, R, Hua, T, Zhu, J, Tuan, N, \& Tan, S. Pharmaceutical Removal in Tropical Subsurface Flow Constructed Wetlands at Varying Hydraulic Loading Rates. Chemosphere (2012). , 87, 273-277.

[17] Wang, R, Korboulewsky, N, Prudent, P, Baldy, V, \& Bonin, G. can Vertical-Flow Wetland Systems Treat High Concentrated Sludge From a Food Industry? A Mesocosm Experiment testing Three Plant Species. Ecological Engineering (2009). , 35, 230-237.

[18] Herouvim, E, Akratos, C, Tekerlekopoulou, A, \& Vayenas, D. Treatment of Olive mill Wastewater in Pilot-Scale Vertical Flow Constructed Wetlands. Ecological Engineering (2011). , 37, 931-939.

[19] Korboulewsky, N, Wang, R, \& Baldy, V. Purification process involved in Sludge Treatment by a Vertical Flow Wetland System: Focus on the Role of the Substrate and Plants on N and P Removal. Bioresource Technology (2012). , 105, 9-14.

[20] Gross, A, Shmueli, O, Ronen, Z, \& Raveh, E. Recycled Vertical Flow Constructed wetland (RVFCW)- A Novel Method of Recycling Greywater for Irrigation in Small Communities and Households. Chemosphere (2007). , 66, 916-923. 
[21] Sklarz, M, Gross, A, Yakirevich, A, \& Soares, M. A Recirculating vertical Flow Constructed wetland for the Treatment of Domestic Wastewater. Desalination (2009). , $246,617-624$.

[22] Kouki, S, Hiri, M, Saidi, F, Belaïd, N, \& Hassen, S. A. Performances of a Constructed Wetland Treating Domestic Wastewaters During a macrophytes Life Cycle. Desalination (2009). , 246, 452-467.

[23] Hijosa-valsero, M, Sidrach-cardona, R, \& Bécares, E. Comparison of Interannual Removal of Various Constructed Wetland Types. Science of the Total Environment (2012). , 430, 174-183.

[24] Ye, F, \& Li, Y. Enhancement of Nitrogen Removal in Towery Hybrid Constructed Wetland to Treat Domestic Wastewater for Small Rural Communities. Ecological Engineering (2009). , 35, 1043-1050.

[25] Gikas, G, \& Tsihrintzis, V. A Small-Size Vertical Flow Constructed Wetland for Onsite Treatment of Household Wastewater. Ecological Engineering (2012). , 44, 337-343.

[26] Abou-elela, S, \& Hellal, M. Municipal Wastewater Treatment Using Vertical Flow Constructed Wetlands Planted with Canna, Phragmites and Cyprus. Ecological Engineering (2012). , 47, 209-213.

[27] Morari, F, \& Giardini, L. Municipal Wastewater Treatment With Vertical Flow Constructed Wetlands for Irrigation Reuse. Ecological Engineering (2009). , 35, 643-653.

[28] Zurita, F, Anda, J, \& Belmont, M. Treatment of Domestic Wastewater and Production of Commercial Flowers in Vertical and Horizontal Subsurface-Flow Constructed Wetlands. Ecological Engineering (2009). , 35, 861-869.

[29] Langergraber, G, Leroch, K, Pressl, A, Sleytr, K, Rohrhofer, R, \& Haberl, R. HighRate Nitrogen Removal in a Two-Stage Subsurface Vertical Flow Constructed Wetland. Desalination (2009). , 246, 55-68.

[30] Tunçsiper, B. Nitrogen removal in a Combined Vertical and Horizontal SubsurfaceFlow Constructed Wetland System. Deaslination (2009). , 247, 466-475.

[31] Panuvatvanich, A, Koottatep, T, \& Kone, D. Influence of Sand Layer Depth and Percolate Impounding Regime on Nitrogen Transformation in Vertical-Flow Constructed Wetlands treating Faecal Sludge. Water Research (2009). , 43, 2623-2630.

[32] Bialowiec, A, Davbies, L, Albuquerque, A, \& Randerson, P. Nitrogen removal From Landfill Leachate in Constructed Wetlands With Reed and Willow: redox Potential in the Root Zone. Journal of Environmental Management (2012). , 97, 22-27.

[33] Molle, P, Prost-boucle, S, \& Lienard, A. Potential for Total Nitrogen Removal by Combining Vertical Flow and Horizontal Flow Constructed Wetlands: A Full-Scale Experiment Study. Ecological Engineering (2008). , 34, 23-29. 
[34] Ouyang, Y, Luo, S, \& Cui, L. Estimation of Nitrogen Dynamics in a Vertical-Flow Constructed Wtland. Ecological Engineering (2011). , 37, 453-459.

[35] Ayaz, S, Aktas, Ő, Findik, N, Akça, L, \& Kinaci, C. Effect of Recirculation on Nitrogen removal in a Hybrid Constructed Wetland System. Ecological Engineering (2012). , 40, 1-5.

[36] Cui Li-HuaOuyang Y., Chen Y., Zhu Xi- Zhen, Zhu Wen-Ling. Removal of Total Nitrogen by Cyperus alternifolius From Wastewaters in Simulated Vertical-Flow Constructed Wetlands. Ecological Engineering (2009). , 35, 1271-1274.

[37] Saeed, T, \& Sun, G. Enhanced Denitrification and Organics Removal in Hybrid Wetland Columns: Comparative Experiments. Bioresource Technology (2011). , 102, 967-974.

[38] Huett, D, Morris, S, Smith, G, \& Hunt, N. Nitrogen and Phosphorus Removal From Plant Nursery Runoff in Vegetated and Unvegetated Subsurface Flow Wetlands. Water Research (2005). , 39, 3259-3272.

[39] Zhang, D, Tan, S, Gersberg, R, Zhu, J, Sadreddini, S, \& Li, Y. Nutrient Removal in Tropical Subsurface Flow Constructed Wetlands Under Batch and Continuous Flow Conditions. Journal of Environmental Management (2012). , 96, 1-6.

[40] Yousefi, Z, \& Mohseni-bandpei, A. Nitrogen and Phpsphorus Removal From Wastewater by Subsurface Wetlands Planted With Iris pseudacorus. Ecological Engineering (2010). , 36, 777-782.

[41] Bustamante, M, Mier, M, Estrada, J, \& Domiguez, C. Nitrogen and Potassium Variation on Contaminant Removal for a Vertical Subsurface Flow Lab Scale Constructed Wetland. Bioresource Technology (2011). , 102, 7745-7754.

[42] Giraldi, D, \& Iannelli, R. Measurements of Water Content Distribution in Vertical Subsurface Flow Constructed Wetlands Using a Capacitance Probe: Benefits and Limitations. Desalination (2009). , 243, 182-194.

[43] Stefanakis, A, \& Tsihrintzis, V. Performance of Pilot-Scale Vertical Flow Constructed Wetlands Treating Simulated Municipal Wastewater: Effect of Various Design Parameters. Desalination (2009). , 248, 753-770.

[44] Ye, J, Wang, L, Li, D, Han, W, \& Ye, C. Vertical Oxygen Distribution and Oxygen Source Analysis for Vertical-Flow Constructed Wetlands Treating Domestic Wastewater. Ecological Engineering (2012). , 41, 8-12.

[45] Zhao, Y. Liu Bo, Zhang W., Ouyang Y., An S. Performance of Pilot-Scale VerticalFlow Constructed Wetlands in Responding to Variation in Influent C/N Ratios of Simulated Urban Sewage. Bioresource Technology (2010). , 101, 1693-1700. 
[46] Yan, C, \& Zhang, H. li Bo, Wang D., Zhao Y., Zheng Z. Effects of Influent C/N Ratios on $\mathrm{CO}_{2}$ and $\mathrm{CH}_{4}$ Emissions From Vertical Subsurface Flow Constructed wetlands Treating Synthetic Municipal Wastewater. Journal of Hazardous Materials (2012).

[47] Prochaska, C, Zouboulis, A, \& Eskridge, K. Preformance of Pilot-Scale Vertical Flow Constructed Wetlands, As Affected by Season, Substrate, Hydraulic Load and Frequency of Application of Simulated Urban Sewage. Ecological Engineering (2007). , 31, 57-66.

[48] Giraldi, D, Vitturi, M, Zaramella, M, Marion, A, \& Iannelli, R. Hydrodynamics of Vertical Subsurface Flow Constructed Wetlands: Tracer Tests WITH Rhodamine WT and Numerical Modelling. Ecological Engineering (2009). , 35, 265-273.

[49] Zapater, M, Gross, A, \& Soares, M. Capacity of an On-site Recirculating Vertical Flow Constructed Wetland to Withstand Disturbances and Highly Variable Influent Quality. Ecological Engineering (2011). , 37, 1572-1577.

[50] Cui, L, Ouyang, Y, Lou, Q, Yang, F, Chen, Y, Zhu, W, \& Luo, S. Removal of Nutrients from Wastewater with Canna indica L. Under Different Vertical-Flow Constructed Wetland Conditions. Ecological Engineering (2010). , 36, 1083-1088.

[51] Zhao, Y, \& Hui, Z. Chao Xu, Nie Er, Li H., He J., Zheng Z. Efficiency of Two-Stage Combinations of Subsurface vertical Down-Flow and Up-Flow Constructed Wetland Systems for Treating Variation in Influent C/N Ratios of Domestic wastewater. Ecological Engineering (2011). , 37, 1546-1554.

[52] Prost-boucle, S, \& Molle, p. Recirculation on a Single Stage of Vertical Flow Constructed Wetland: Treatment Limits and Operation Modes. Ecological Engineering (2012). , 43, 81-84.

[53] Stefanakis, A, \& Tsihrintzis, V. Effects of Loading, Resting Period, Temperature, Porous Media, vegetation and Aeration on Performance of Pilot-Scale Vertical Flow Constructed Wetlands. Chemical Engineering Journal (2012).

[54] Saeed, T, \& Sun, G. A Review on Nitrogen and Organics removal Mechanisms in Subsurface Flow Constructed Wetlands: Dependency on Environmental Parameters, Operating Conditions and Supporting Media. Journal of Environmental management (2012). , 112, 429-448.

[55] Kantawanichkul, S, Kladprasert, S, \& Brix, H. Treatment of High-Strength Wastewater in Tropical vertical Flow Constructed Wetlands Planted with Typha angustifolia and Cyperus involucratus. Ecological Engineering (2009). , 35, 238-247.

[56] Lio, X, Huang, S, Tang, T, Liu, X, \& Scholz, M. Growth Characteristics and nutrient removal Capability of Plants in Subsurface Vertical Flow Constructed Wetlands. Ecological Engineering (2012). , 44, 189-198. 
[57] Iamchaturapatr, J. Yi Su, Rhee J. Nutrient Removal by 21 Aquatic Plants for Vertical Free Surface-Flow (VFS) Constructed Wetland. Ecological Engineering (2007). , 29, 287-293.

[58] Tietz, A, Langergraber, G, Watzinger, A, Haberl, R, \& Kirschner, A. Bacterial Carbon Utilization in Vertical Subsurface Flow Constructed Wetlands. Water Research (2008). , 42, 1622-1634.

[59] Tietz, A, Kirschner, A, Langergraber, G, Sleytr, K, \& Haberl, R. Characterisation of Microbial Biocenosis in Vertical Subsurface Flow Constructed Wetlands. Science of the Total Environment (2007). , 380, 163-172.

[60] Sleytr, K, Tietz, A, Langergraber, G, Haberl, R, \& Sessitsch, A. Diversity of Abundant Bacteria in Subsurface vertical Flow Constructed Wetlands. Ecological Engineering (2009). , 35, 1021-1025.

[61] Fuchs, V, Mihelcic, J, \& Gierke, J. Life Cycle Assessment of Vertical and Horizontal Flow Constructed Wetlands for Wastewater Treatment Considering Nitrogen and Carbon Greenhouse Gas Emissions. Water research (2011). , 45, 2073-2081.

[62] Vohla, C, Kõiv, M, Bavor, H, Chazarenc, F, \& Mander, Ú. Filter Materials for Phosphorus Removal from Wastewater in Treatment Wetlands- A Review. Ecological Engineering (2011). , 37, 70-89.

[63] Wang, D, Jin, X, Zhang, H, Zhang, X, Zeng, H, You, S, Zhao, W, Xu, Z, \& Wu, Y. Research Progres on Phosphorus Removal in Substrates of Constructed Wetlands. Bioinformatics and Biomedical Engineering, (2009). rd International Conference on; ICBBE 2009. , 1-6.

[64] Mateus, D, Vaz, M, \& Pinho, H. Fragmented limestone Wastes as a Constructed Wetland Substrate for Phosphorus Removal. Ecological Engineering (2012). , 41, 65-69.

[65] Brooks, A, Rozenwald, M, Geohring, L, Lion, L, \& Steenhuis, T. Phosphorus Removal by Wollastonite: A Constructed Wetland Substrate. Ecological Engineering (2000). , $15,121-132$.

[66] White, S, Taylor, M, Albano, J, Whitwell, T, \& Kleine, S. Phosphorus Retention in Lab and Field-scale Subsurface-Flow Wetlands Treating Plant Nursery Runoff. Ecological Engineering (2011). , 37, 1968-1976.

[67] Prochaska, C, \& Zouboulis, A. Removal of Phosphates by Pilot Vertical-Flow Constructed Wetlands Using a mixture of Sand and Dolomite as Substrate. Ecological Engineering (2006). , 26, 293-303.

[68] Sun, G, \& Austin, D. Completely Autotrophic Nitrogen-removal Over Nitrite in LabScale Constructed Wetlands: Evidence from a Mass Balance Study. Chemosphere (2007). , 68, 1120-1128. 
[69] Akinbile, C, Yusoff, M, \& Zuki, A. Landfill Leachate Treatment Using Sub-Surface Flow Constructed Wetland by Cyperus haspan. Waste Management (2012). , 32, 1387-1393.

[70] Justin, M, \& Zupancic, M. Combined Purification and reuse of Landfill Leachate by Constructed Wetland and Irrigation of Grass and Willows. Desalination (2009). , 246, 157-168.

[71] Bulc, T. Long Term Performance of a Constructed Wetland for Landfill Leachate Treatment. Ecological Engineering (2006). , 26, 365-374.

[72] Kadlec, R, \& Zmarthie, L. Wetland Treatment of Leachate from a Closed Landfill. Ecological Engineering (2010). , 36, 946-957.

[73] Sawaittayothin, V, \& Polprasert, C. Nitrogen Mass balance and Microbial Analysis of Constructed Wetlands Treating Municipal Landfill Leachate. Bioresource Technology (2007). , 98, 565-570.

[74] Lavrova, S, \& Koumanova, B. Influence of Recirculation in a Lab-Scale Vertical Flow Constructed Wetland on the Treatment Efficiency of Landfill Leachate. Bioresource Technology (2010). , 101, 1756-1761.

[75] Yalcuk, A, \& Ugurlu, A. Comparison of Horizontal and Vertical Constructed Wetland System for Landfill Leachate treatment. Bioresource technology (2009). , 100, 2521-2526.

[76] Standard Methods for the Examination of Water and Wastewaterth ed., (1992).

[77] Zhao, Y, Sun, G, \& Allen, S. Purification capacity of a highly loaded laboratory scale tidal flow reed bed system with final recirculation. Science of the Total Environment (2004). , 330, 1-8.

[78] Zhao, Y, Sun, G, \& Allen, S. Anti-sized reed bed system for animal wastewater treatment: a comparative study. Water Research (2004). , 38, 2907-2917.

[79] Sun, G, Zhao, Y, \& Allen, S. Enhanced removal of organic matter and ammoniacalnitrogen in a column experiment of tidal flow constructed wetland system. Journal of Biotechnology (2005). , 115, 189-197.

[80] Lavrova, S, \& Koumanova, B. Polishing of aerobically treated wastewater in a constructed wetland system. Journal of the University of Chemical Technolgy and Metallurgy (Sofia) (2007). , 42(2), 195-200.

[81] Lavrova, S. Koumanova, Doprechistvane v konstruirana vlazna zona na aerobno tretirani otpaduchni vodi ot svinefermi, Proceedings of the International Conference of the Food Science, Engineering and Technologies, 19-20 October, Plovdiv 2007, iss. 1, (2007). in Bulgarian)., 34 
[82] Lavrova, S, \& Koumanova, B. A comparative study of the nitrogen rich pig slurry treatment in aerobic bioreactor and in constructed vertical flow wetland system. Journal of Environmental Protectection and Ecology (2009). , 4, 913-920.

[83] Saeed, T, \& Sun, G. A review on nitrogen and organics removal mechanisms in subsurface flow constructed wetlands: Dependency on environmental parameters, operating conditions and supporting media. Journal of Environmental Management (2012). , 112, 429-448.

[84] Cannon, A, Gray, K, Biddlestone, A, \& Thayanithy, K. Pilot-scale development of a bioreactor for the treatment of dairy dirty water. Journal of Agricultural Engineering Research (2000). , 77, 327-334.

[85] Schipper, L, Cooper, A, Harfoot, C, \& Dyck, W. Regulators of denitrification in an organic riparian soil. Soil Biology and Biochemistry (1993). , 25(7), 925-933.

[86] Stefanakis, A, \& Tsihrintzis, V. Effects of loading, resting period, temperature, porous media, vegetation and aeration on performance of pilot-scale vertical flow constructed wetlands. Chemical Engineering Journal (2012).

[87] Prost-boucle, S, \& Molle, P. Recirculation on a single stage of vertical flow constructed wetland: Treatment limits and operation modes. Ecological Engineering (2012). , $43,81-84$.

[88] Lavrova, S, \& Koumanova, B. Landfill leachate purification in a vertical flow constructed wetland with/without preliminary aerobic treatment. Journal of the University of Chemical Technology and Metallurgy (2011). , 46(3), 299-304.

[89] Faulwetter, J, Gagnon, V, Sundberg, C, Chazarenc, F, Burr, M. D, Brisson, J, Camper, A. K, \& Stein, O. R. Microbial processes influencing performance of treatment wetlands: A review. Ecological Engineering (2009). , 35, 987-1004.

[90] Hammer, M. Hammer Jr. Water and Wastewater Technology, $4^{\text {th }}$ ed. (2001). PrenticeHall, Inc. Upper Saddle River, NJ, USA.

[91] Vymazal, J. Removal of nutrients in various types of constructed wetlands. Science of Total Environment (2007). , 380, 48-65.

[92] Watson, J, Reed, S, Kadlec, R, Knight, R, \& Whitehouse, A. Performance expectations and loading rates for constructed wetlands. In: Hammer, D.A. (ed.), Constructed wetlands for wastewater treatment. Municipal, industrial and agricultural. Lewis publishers, Chelsea, Michigan. (1989). , 319-358.

[93] Huett, D, Morris, S, Smith, G, \& Hunt, N. Nitrogen and phosphorus removal from plant nursery runoff in vegetated and unvegetated subsurface flow wetlands. Water research (2005). , 39, 3259-3272. 
[94] Hamilton, H, Nix, P, \& Sobolavski, A. An overview of constructed wetlands as alternatives to conventional waste treatment systems. Water Pollution Research Journal of Canada (1993). , 28, 529-548.

[95] Coleman, J, Hench, K, Garbutt, K, Sexstone, A, Bissonnelte, G, \& Skousen, J. Treatment of domestic wastewater by three plant species in constructed wetland. Wter Air Soil Pollution (2001). , 128, 283-295.

[96] Hunter, R, Combs, D, \& George, D. Nitrogen, phosphorus, and organic carbon removal in simulated wetland treatment systems. Archives of Environmental Health (2001). , 41, 274-281. 
